\title{
Average Hourly Concentrations of Air Contaminants in Selected Urban, Town, and Rural Sites
}

\author{
Robert Cichowicz $^{1}$ (1) $\cdot$ Artur Stelęgowski $^{1}$
}

Received: 23 December 2018 / Accepted: 1 April 2019 / Published online: 10 April 2019

(C) The Author(s) 2019

\begin{abstract}
The inhabitants of cities, towns, and villages are exposed to different levels of air pollution, which also vary throughout the day. Information regarding episodes of poor and good air quality enables planning to mitigate the risks and maximize the benefits of spending time outdoors. In this work, an analysis was made of the state of air quality 2012-2016, using data gathered from automatic measuring stations located in five cities ( $>50,000$ inhabitants), five towns (5000-50,000 inhabitants), and five villages $(<5000$ inhabitants) in five neighboring provinces in central Poland, in Central Europe. The monitoring stations were designated as "city background", "town background", and "rural background". More than 3 million pieces of data were collected from 15 monitoring stations. This allowed the average daily changes in the concentration of air pollutants $\left(\mathrm{NO}_{2}\right.$ and $\left.\mathrm{NO}_{\mathrm{x}}, \mathrm{O}_{3}, \mathrm{SO}_{2}, \mathrm{CO}, \mathrm{PM}_{10}, \mathrm{PM}_{2.5}, \mathrm{C}_{6} \mathrm{H}_{6}\right)$ to be determined, depending on the type of station and the size of the settlement unit in both winter periods and summer periods. As a result, the most and least favorable hours in terms of levels of air pollution were identified. This information could help to inform air quality management in modern cities, towns, and villages and to improve the quality of life, particularly among those most susceptible to the negative effects of air pollution, such as the elderly and children.
\end{abstract}

\section{Graphical Abstract}

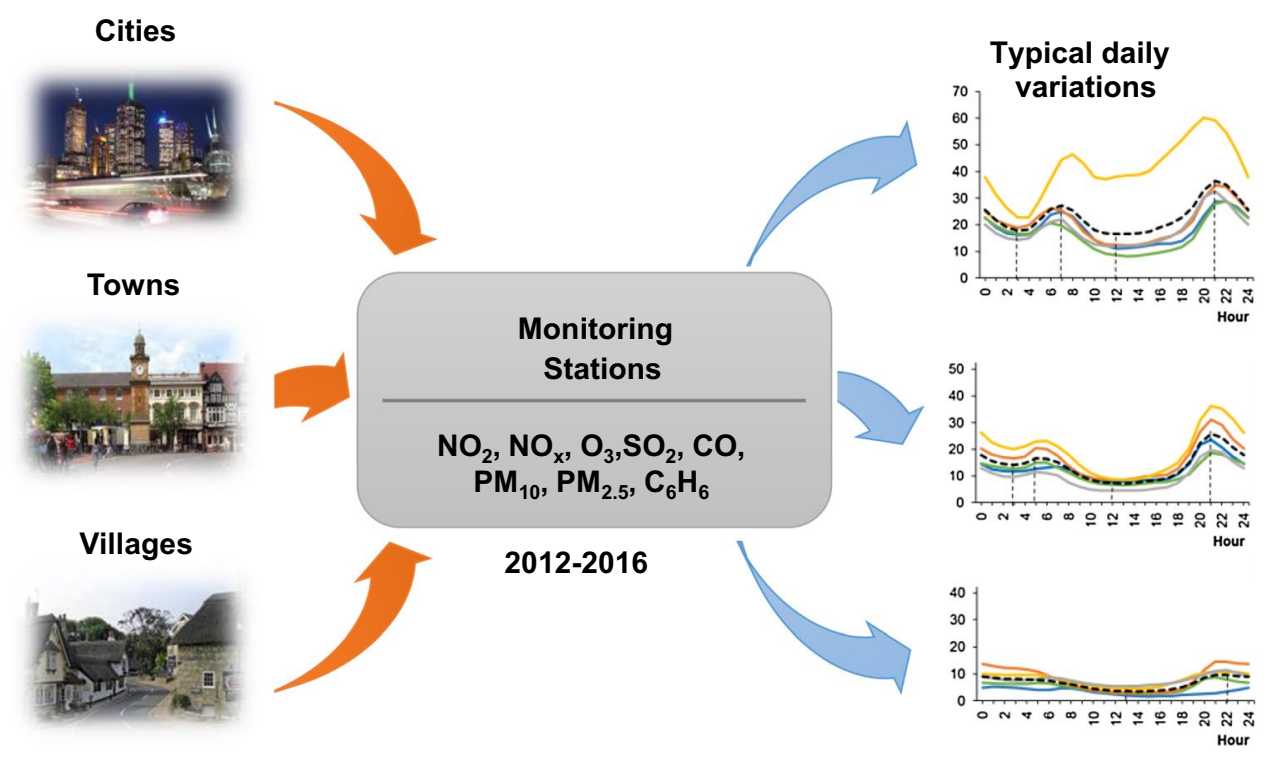

Robert Cichowicz

robert.cichowicz@p.lodz.pl

Faculty of Civil Engineering, Architecture and Environmental Engineering, Lodz University of Technology, Lodz, Poland 


\section{State-of-the-Art}

Worldwide air quality poses a risk both to human health and the wider environment (Agudelo-Castañeda et al. 2019; Ramírez et al. 2019; Oliveira et al. 2019). Studies on air pollution focus not only on inhabited areas (Cichowicz et al. 2017; Cichowicz 2018; Pérez et al. 2010) but also on agricultural and undeveloped areas, which are used as background measurements (Hagenbjörk et al. 2017; Putaud et al. 2004; Zheng et al. 2010). In many countries, including in Europe, air quality assessments use measurements performed by automatic measuring stations (Agudelo-Castaneda and Teixeira 2014; Malley et al. 2018; Wielgosiński et al. 2018) and air quality modeling (Cichowicz and Stelegowski 2018a; Inness et al. 2013; Menut et al. 2012). Usually, the average annual, seasonal, and monthly concentrations of air pollutants are analyzed (Cichowicz et al. 2017; Guerreiro et al. 2010; Malley et al. 2018). Much less information is available regarding daily fluctuations (Liu et al. 2014; Zhao et al. 2009). Daily variations in air pollution occur due to the high variability of sociophysical and chemical parameters during the day (Menut et al. 2012; Pérez et al. 2010). These changes depend largely on the day of the week (work days or weekends) (Feng et al. 2014; Chaloulakou and Mavroidis 2002) and the season (Vouitsis et al. 2015). The average hourly concentrations of air pollutants are usually analyzed only for cities (Agudelo-Castaneda and Teixeira 2014; Vouitsis et al. 2015) and in the vicinity of busy roads (Moreno et al. 2013; Pérez et al. 2010). There are few air-quality analyses on other types of area, especially for settlement units of different sizes, and those focus on average annual and seasonal pollution levels (Hagenbjörk et al. 2017; Malley et al. 2018; Putaud et al. 2004; Tecer and Tagil 2014) and only occasionally daily variations (Zheng et al. 2010).

\section{Outdoor and Indoor Air Pollution}

Concentrations of air pollutants depend on city density and on urban planning, and the level of industrialization also has an impact (Landim et al. 2018; León-Mejía et al. 2018; Saikia et al. 2018). The daily activity patterns of people, including time spent at home, working hours, and travel, are specific to particular areas and fluctuate during the day. The emission of air pollutants associated with such activities, and the concentrations of pollutants in the ambient air therefore vary (Cichowicz et al. 2017; Fenger 1999; Nicolai et al. 2003). Although people spend only 10-20\% of their days outdoors, it is still important to provide information on air quality, especially for those most susceptible to the negative effects of air pollution, such as children, the elderly, and people with asthma and respiratory illnesses (Künzli et al. 2000; WHO 2000, 2005). Such information makes it possible for people to reduce their exposure to air pollution, for example in response to recommendations regarding the "most" and "least" favorable hours for staying outdoors. When there are high concentrations of air pollutants in the air, it is advisable to stay indoors. This is due to the inertia of the air in buildings, which can cause a "shift" and "lowering" of the daily maximum concentrations of several pollutants (Bouhambra et al. 2000; Hayes 1991; Chaloulakou and Mavroidis 2002). The flow balance of air pollution inside a building depends not only on outdoor air quality but also on the structure and airtightness of the building, as well as indoor sources of pollution (Cichowicz et al. 2016; Cichowicz and Stelęgowski 2018b; Colbeck et al. 2008; De Paoli et al. 2018). However, according to the literature, there may be shifts of approximately $1 \mathrm{~h}$ and reductions of approximately $60 \%$ for CO (Chaloulakou and Mavroidis 2002), of $90 \%$ for $\mathrm{O}_{3}$ (Hayes 1991) and approximately $30 \%$ for benzene (Bouhambra et al. 2000). When there are low concentrations of pollutants outdoors, the situation is reversed. During such periods, it is better to stay outside, where concentrations can be half those in buildings (Chaloulakou and Mavroidis 2002).

\section{Automatic Measuring Stations in Cities, Towns, and Villages}

Hourly measurements of pollutant concentrations in the ambient air are taken across a network of national air monitoring stations in Europe (Guerreiro et al. 2010; EEA 2016). These measurement stations are located in the vicinity of point, areal, and linear emission sources and provide data on the air quality in areas of, inter alia, "urban traffic/kerbside" (UT), "urban background" (CB), "suburban background" (SB), "rural background" (RB), and "natural background" (NB) pollution (Putaud et al. 2004).

There are various classifications of settlement units in European Union countries. To unify this division, the Organization for Economic Cooperation and Development with European Commission (OECD-EC) introduced the definition of a city as an urbanized area with a population of more than 50,000 and population density above 1500 inhabitants $\mathrm{km}^{-2}$ (Dijkstra and Poelman 2012). According to the definition developed in the European Territorial Observatory Network program (ESPON), towns are urbanized areas with populations of 5000-50,000 and 
population densities of 300-1500 inhabitants $\mathrm{km}^{-2}$ (Servillo et al. 2014).

\section{Daily Variations in Air Pollution}

Daily variations in air-pollution level depend, to a large extent, on both meteorological conditions (Pérez et al. 2010) and human activity. Human activity profiles are relatively stable in particular areas, resulting in distinctive patterns air pollutant emissions (Gaffron 2012; Menut et al. 2012). However, the concentrations of air pollutants in a given area are influenced by many factors, none of which often is decisive. Depending on the location of the measuring station, the levels of air pollution can be more or less closely associated with particular factors. This has been confirmed by studies in which, for example, an analysis of the urban background pollution in the cities Canoas and Esteio in Brazil showed a correlation between $\mathrm{O}_{3}$ and solar radiation intensity, and no correlation between $\mathrm{PM}_{10}$ and air temperature (Agudelo-Castaneda and Teixeira 2014, 2017; Vouitsis et al. 2015). The Pearson correlation coefficient between $\mathrm{O}_{3}$ and radiation intensity was 0.558 (average) and -0.186 (low) for $\mathrm{PM}_{10}$ and ambient temperature (Agudelo-Castaneda and Teixeira 2014). However, at a short distance from the emission source, the relationship was much stronger. This was confirmed by analyses carried out near a busy road in the city of Thessaloniki (Greece). The Pearson correlation coefficient between NO and CO and road traffic intensity was significantly stronger: 0.91 and 0.94 respectively in summer, and 0.89 and 0.40 in winter (Vouitsis et al. 2015). The changes in NO concentration during winter and summer seem related mainly to changes in road traffic intensity. Changes in $\mathrm{CO}$ concentration in winter were possibly associated with other factors, such as emissions from fuel combustion for heating purposes.

\section{Characteristics of the Tested Area}

Poland is located in a temperate transitional climate zone. There are low temperatures in winter, reaching approximately $-14{ }^{\circ} \mathrm{C}$ (5th percentile) and on average ranging from approximately -3 to $+1{ }^{\circ} \mathrm{C}$ (http://old.imgw.pl/ klimat), depending on the region. As a result, there are high levels of pollution from fuel combustion for heating purposes (nonindustrial combustion). In contrast, temperatures in summer are significantly higher, reaching approximately $+28{ }^{\circ} \mathrm{C}$ (95th percentile), and on average ranging from approximately +13 to $+19{ }^{\circ} \mathrm{C}$ (http:// old.imgw.pl/klimat), depending on the region. Therefore, there are high levels of pollution from transport in summer. Most of Poland is located in the North European Plain, consisting of low plains. The north part of Poland is a coastal lowland adjacent to Baltic Sea, and the south part includes highlands and the Carpathian Mountains. The analyzed regions of Great Poland, Lodz, and Masovia are located in the lowlands (elevation up to $300 \mathrm{~m}$ ). The Lublin region includes mostly lowlands, highlands (elevation up to $390 \mathrm{~m}$ ), and Lower Silesia consists of lowlands, highlands (up to $718 \mathrm{~m}$ ), and mountains (up to $1603 \mathrm{~m}$ ). The chosen areas are similar for weather conditions. The annual average air temperature is $8 \pm 1{ }^{\circ} \mathrm{C}$, precipitation is approximately $600 \mathrm{~mm}$, with higher values (up to $1300 \mathrm{~mm}$ ) in the mountains (SP 2018). However, the prevailing rainfall occurs in summer. The mean monthly humidity usually range from 60 to $90 \%$. The dominant wind direction is west, and the average velocity is $3 \mathrm{~m} \mathrm{~s}^{-1}$. The average insolation is $1600 \mathrm{~h}$, and average solar radiation is $1000 \mathrm{kWh} / \mathrm{m}^{2}$. In 2015 , approximately $91 \%$ of energy was generated from nonrenewable sources in Poland, primarily from hard coal and lignite (51\%), crude oil (25\%), and natural gas (15\%) (IEA 2017). The share of urban population in the total population of a region amounts to approximately $46 \%$ in Lublin voivodeship, 55\% in Greater Poland, 64\% in Lodz and Masovia, and $69 \%$ in Lower Silesia. The dominant air contamination sources in the chosen areas are power industry, industrial and nonindustrial combustion, and road transport. Those economy sectors contribute to $97 \%$ of $\mathrm{SO}_{2}, 80 \%$ of $\mathrm{NO}_{\mathrm{x}}$, and 70\% of $\mathrm{PM}_{10}$ emissions in Poland (Dębski et al. 2015; SP 2017). The amount of total gaseous emissions form point sources in 2017 was $12.0 \times 10^{6} \mathrm{Mg} / \mathrm{year}$ in Lower Silesia, $14.4 \times 10^{6} \mathrm{Mg} /$ year for Greater Poland, $43.2 \times 10^{6}$ $\mathrm{Mg} /$ year for Lodz, $29.1 \times 10^{6} \mathrm{Mg} /$ year for Masovia, and $5.0 \times 10^{6} \mathrm{Mg} /$ year for Lublin region. Dust emissions were $1.9 \times 10^{3} \mathrm{Mg} /$ year, $4.0 \times 10^{3} \mathrm{Mg} /$ year, $2.3 \times 10^{3} \mathrm{Mg} /$ year, $2.7 \times 10^{3} \mathrm{Mg} /$ year, and $1.7 \times 10^{3} \mathrm{Mg} /$ year respectively (https://bdl.stat.gov.pl). High point emissions in Lodz region were mainly caused by power industry, especially by large power plant "PGE GiEK" Belchatow. This power plant has $5342 \mathrm{MW}_{\mathrm{e}}$ electric power and uses brown coal as a fuel (Cichowicz and Stelegowski 2018c). It is placed $35 \mathrm{~km}$ from the analyzed location in Piotrków Trybunalski city, $60 \mathrm{~km}$ Lodz city, and $100 \mathrm{~km}$ from Gajew village. In Greater Poland region, there is the "ZE PAK" (http://zepak .pl/en) power plant complex $\left(2512 \times \mathrm{MW}_{\mathrm{e}}\right.$, fuel: brown coal), placed $10-30 \mathrm{~km}$ from the analyzed locations in Konin city, $35 \mathrm{~km}$ from Piaski village, and $130 \mathrm{~km}$ from Poznan city. Also, each city and town in this analysis has its own, but smaller $\left(<500 \mathrm{MW}_{\mathrm{e}}\right)$, power or combined heat and power plant, providing energy and/or heat for central part of its urbanized area.

Due to the specific characteristics of emissions in different areas, it was decided to analyze the changes in the 


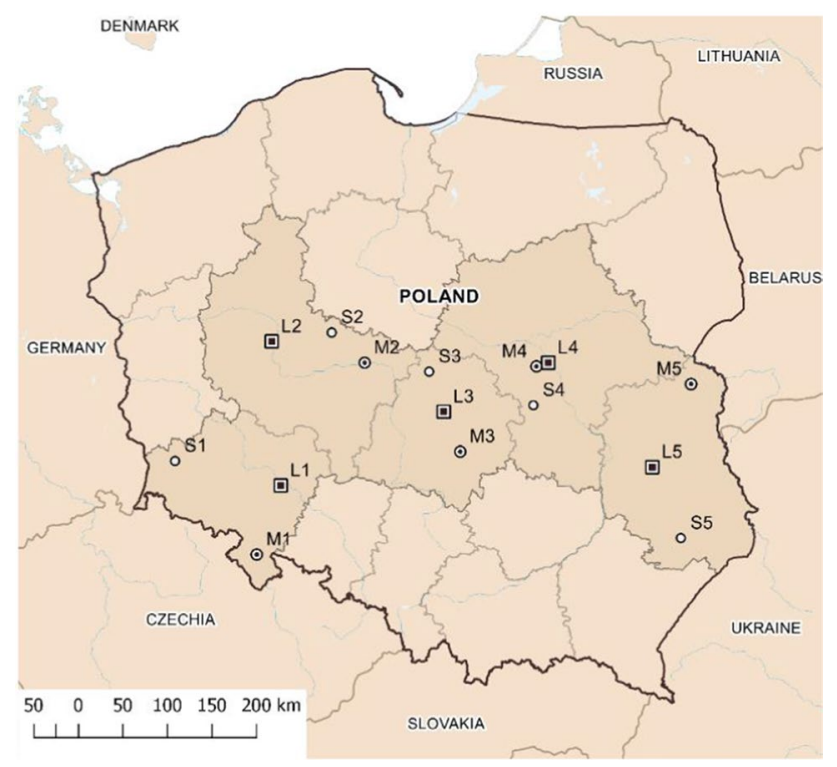

Fig. 1 Location of measuring stations in selected cities, towns, and villages in Poland

average hourly concentrations of air pollutants at various locations in Poland, depending on the size of the settlement unit. The analysis focused on the selected air pollutants, which are harmful to human health: the gaseous substances $\mathrm{NO}_{2}, \mathrm{NO}_{\mathrm{x}}\left(\mathrm{NO}+\mathrm{NO}_{2}\right), \mathrm{SO}_{2}, \mathrm{O}_{3}$ and $\mathrm{CO}$, as well as the dusts $\mathrm{PM}_{10}$ and $\mathrm{PM}_{2.5}$ and benzene $\left(\mathrm{C}_{6} \mathrm{H}_{6}\right)$. The analysis covered a period of 5 years from January 2012 to December 2016. The data were gathered from automatic air monitoring stations and were made available by the Voivodship Inspectorates for Environmental Protection (WIOŚ) and by the Main Inspectorate for Environmental Protection (GIOŚ) in Poland (http://powietrze.gios.gov.pl/pjp/current). The monitoring stations were categorized based on the character of the emissions, as city background (CB), town background (TB), or rural background (RB). Data from 15 monitoring stations were selected for analysis: five stations located in cities (CB stations), five in towns (TB stations), and five in villages (RB stations). The CB and TB stations were located in the surroundings of dense residential and service buildings, away from large point air pollution sources. RB measuring stations were located in the agriculture areas.

Due to the prevailing western and south-western wind directions in Poland, all the selected measuring stations were on the "west-east" line, between 50 and $53^{\circ} \mathrm{N}$ latitude and $15-24^{\circ} \mathrm{E}$ longitude. This area comprised five provinces in central Poland (Fig. 1). In the following analysis, the locations are designated using symbols relating to the size of the settlement units and their location in a particular voivodship: L—city, M-town, S-village; 1 - Lower Silesia voivodship, 2-Greater Poland voivodship, 3-Lodz voivodship, 4-Masovian voivodeship, 5-Lublin voivodeship (Tables 1, 2, 3).

The measurements were made at automatic air monitoring stations, according to the reference or equivalent methods (Table 4). However, due to technical/service breaks in
Table 1 Location of CB measurement stations in cities

\begin{tabular}{llclll}
\hline Symbol & City name & $\begin{array}{l}\text { Population } \\
\text { (inhabitants) }\end{array}$ & $\begin{array}{l}\text { Density (inhabit- } \\
\text { ants km }{ }^{-2} \text { ) }\end{array}$ & Station address & City size \\
\hline L1 & Wrocław & 639,000 & 2181 & Korzeniowskiego St. & XL \\
L2 & Poznań & 539,000 & 2057 & Polanka St. & XL \\
L3 & Lódź & 690,000 & 2354 & Gdańska St. & XL \\
L4 & Warsaw & $1,765,000$ & 3412 & Marszałkowska St. & XXL \\
L5 & Lublin & 340,000 & 2310 & Obywatelska St. & L \\
\hline
\end{tabular}

Population status as of 31 Dec 2017. City size is defined according to the nomenclature of OECD-EC classification, depending on the population of urban city center, as: L-large city, XL—extra-large city, XXL-extra extra-large city

Table 2 Location of TB measurement stations in towns

\begin{tabular}{|c|c|c|c|c|c|}
\hline Symbol & Town name & $\begin{array}{l}\text { Population (inhab- } \\
\text { itants) }\end{array}$ & $\begin{array}{l}\text { Density (inhabit- } \\
\text { ants } \mathrm{km}^{-2} \text { ) }\end{array}$ & Station address & Town size \\
\hline M1 & Kłodzko & 27,000 & 1098 & Szkolna St. & Medium SMST \\
\hline M2 & Konin & 75,000 & 919 & Wyszyńskiego St. & Large SMST \\
\hline M3 & Piotrków Trybunalski & 74,000 & 1114 & Krakowskie Przedmieście St. & Large SMST \\
\hline M4 & Piastów & 23,000 & 3977 & Pułaskiego St. & Small SMST \\
\hline M5 & Biała Podlaska & 57,000 & 1159 & Orzechowa St. & Large SMST \\
\hline
\end{tabular}

Population status as of 31 Dec 2017. City size is defined according to the OECD-EC classification 
Table 3 Location of RB measurement stations in villages

\begin{tabular}{lllll}
\hline Symbol & Village name & $\begin{array}{l}\text { Population } \\
\text { (inhabit- } \\
\text { ants) }\end{array}$ & Latitude & Longitude \\
\hline S1 & Osieczów & 345 & $51^{\circ} 19^{\prime} 03.5^{\prime \prime} \mathrm{N}$ & $15^{\circ} 25^{\prime} 54.2^{\prime \prime} \mathrm{E}$ \\
S2 & Piaski & 124 & $52^{\circ} 30^{\prime} 05.0^{\prime \prime} \mathrm{N}$ & $17^{\circ} 46^{\prime} 24.5^{\prime \prime} \mathrm{E}$ \\
S3 & Gajew & 114 & $52^{\circ} 08^{\prime} 35.7^{\prime \prime} \mathrm{N}$ & $19^{\circ} 41^{\prime} 49.0^{\prime \prime} \mathrm{E}$ \\
S4 & Belsk Duży & 790 & $51^{\circ} 50^{\prime} 06.4^{\prime \prime} \mathrm{N}$ & $20^{\circ} 47^{\prime} 29.6^{\prime \prime} \mathrm{E}$ \\
S5 & Obrocz & 525 & $50^{\circ} 35^{\prime} 26.9^{\prime \prime} \mathrm{N}$ & $22^{\circ} 59^{\prime} 52.4^{\prime \prime} \mathrm{E}$ \\
\hline
\end{tabular}

Population status as of 31 Dec 2009

the operation of individual measuring stations, full data could not be obtained for all gaseous substances and dusts. Therefore, only the data from years with at least $75 \%$ completeness for a particular station were used in the analysis. The average hourly concentrations were thus determined based on the number of years that met this criterion for a given station (Table 5).

In Poland, the levels and nature of air pollutants vary significantly between in winter periods (WPs) and summer periods (SPs). Therefore, the measurements were divided into two seasons. It was assumed that WP lasted from October 1 to March 31 and covered the entire heating season, whereas SP lasted from May 1 to August 31 and covered the vegetation period.

\section{Results and Discussion}

The analysis of average hourly pollutant concentrations in the ambient air at stations $\mathrm{CB}, \mathrm{TB}$, and $\mathrm{RB}$, in $\mathrm{WP}$ and $\mathrm{SP}$ in the years 2012-2016, revealed daily variations in air pollution levels. The periods during a "typical" day were identified when the daily maximum and daily minimum average hourly concentrations of pollutants occurred.

Mean hourly $\mathrm{NO}_{2}$ concentrations in WPs ranged from 14.12 to $57.27 \mu \mathrm{g} \mathrm{m}^{-3}$ in cities, from 11.06 to $32.98 \mu \mathrm{g} \mathrm{m}^{-3}$ in towns, and from 9.10 to $16.41 \mu^{g^{-3}}$ in rural areas (Fig. 2). In SPs, the mean hourly $\mathrm{NO}_{2}$ concentrations ranged from 8.29 to $60.10 \mu \mathrm{g} \mathrm{m}^{-3}$, from 4.47 to $36.33 \mu \mathrm{g} \mathrm{m}^{-3}$, and

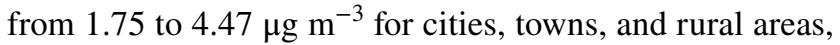

Table 5 Number of measuring stations and the number of years that met the criterion of completeness for results

\begin{tabular}{llll}
\hline Pollutant & \multicolumn{2}{l}{ Stations $\times$ years } \\
\cline { 2 - 4 } & CB stations & TB stations & RB stations \\
\hline $\mathrm{NO}_{2}$ & 25 & 22 & 25 \\
$\mathrm{NO}_{\mathbf{x}}$ & 25 & 20 & 25 \\
$\mathrm{O}_{3}$ & 14 & 23 & 25 \\
$\mathrm{SO}_{2}$ & 20 & 24 & 25 \\
$\mathrm{CO}$ & 23 & 10 & 5 \\
$\mathrm{PM}_{10}$ & 18 & 15 & 7 \\
$\mathrm{PM}_{2.5}$ & 12 & 2 & n/a \\
benzene & 12 & n/a & n/a \\
\hline
\end{tabular}

respectively (Fig. 3). This means that the lowest concentrations occurred during SPs and the highest in winter, except at locations L4 and M4 (stations in the Warsaw city and the town of Piastów in the Mazovian Province). The shape of the $\mathrm{NO}_{2}$ daily profile was always close to a bimodal distribution, with two distinct minima and maxima. The daily maximum concentration was higher in the evenings than in the morning. The lowest concentrations occurred in SPs in the afternoon and, importantly, remained at a similar level for 6-12 h. However, these periods of low $\mathrm{NO}_{2}$ concentrations were much shorter, lasting 1-4 h. The shapes of the hourly profiles for the same type of settlement unit were similar.

The average hourly $\mathrm{NO}_{\mathrm{x}}$ concentrations in WPs ranged from 20.27 to $142.77 \mu \mathrm{g} \mathrm{m}^{-3}$ in cities, from 16.54 to $61.86 \mu \mathrm{g} \mathrm{m}^{-3}$ in towns, and from 10.74 to $18.33 \mu \mathrm{g} \mathrm{m}^{-3}$ in rural areas (Fig. 4). The concentrations were lower in SPs and ranged from 12.56 to $110.57 \mu \mathrm{g} \mathrm{m}^{-3}$, from 8.11 to $45.79 \mu \mathrm{g} \mathrm{m}^{-3}$, and from 2.16 to $18.80 \mu \mathrm{g} \mathrm{m}^{-3}$, respectively (Fig. 5). The shape of the $\mathrm{NO}_{\mathrm{x}}$ daily profiles was close to a bimodal distribution, similar to the $\mathrm{NO}_{2}$ profiles. However, in the case of $\mathrm{NO}_{\mathrm{x}}$ the morning and evening peaks had similar values. This was most likely caused by NO emissions resulting from the morning rush hours. However, in summer in the cities of Wrocław (L1) and Warsaw (L4), the morning $\mathrm{NO}_{\mathrm{x}}$ peak concentrations were higher than those in the evening, probably due to the heavier traffic congestion. The shapes of the $\mathrm{NO}_{\mathrm{x}}$ profiles were similar for particular types of settlement unit. The $\mathrm{NO}_{x}$ level was also lower during SPs
Table 4 Methods of measuring air pollution at measuring stations

\begin{tabular}{ll}
\hline Pollutant & Measuring method \\
\hline $\mathrm{NO}, \mathrm{NO}_{2}$ & Chemiluminescence, according to EN 14211; precision $\pm 0.5 \%$ \\
$\mathrm{SO}_{2}$ & Ultraviolet fluorescence, according to EN 14212; precision $\pm 1 \%$ \\
$\mathrm{CO}$ & Infrared spectroscopy, according to EN 14626; precision $\pm 0.1 \mathrm{ppm}$ \\
$\mathrm{O}_{3}$ & Ultraviolet photometry, according to EN 14625; precision $\pm 1 \mathrm{ppb}$ \\
$\mathrm{PM}_{10}, \mathrm{PM}_{2.5}$ & Beta attenuation, according to EN 12341; precision $\pm 2 \mu \mathrm{g} \mathrm{m}^{-3}$ \\
benzene & Gas chromatography with flame-Ionization detection, according to \\
& EN 16450:2017-05; precision $\pm 3.0 \%$ \\
\hline
\end{tabular}



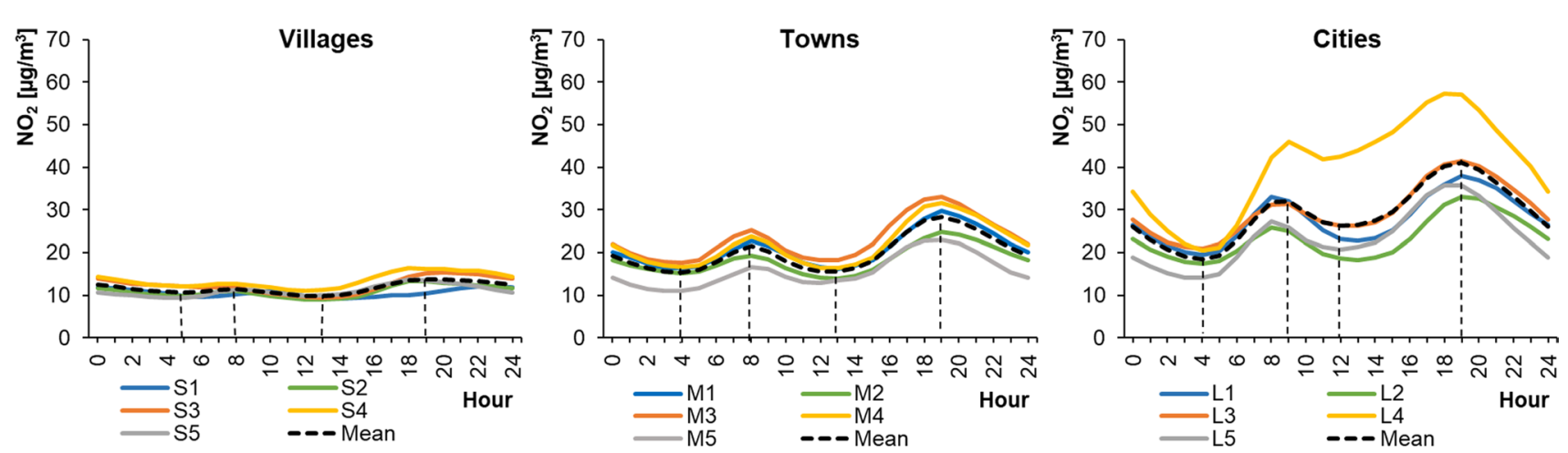

Fig. 2 Average hourly $\mathrm{NO}_{2}$ concentrations in winter periods
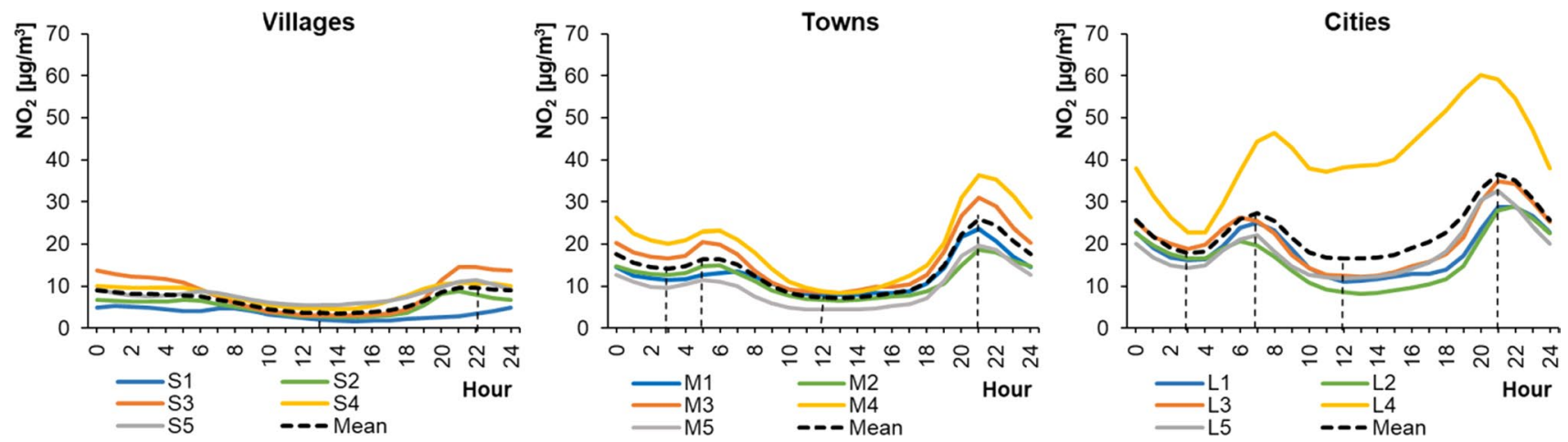

Fig. 3 Average hourly $\mathrm{NO}_{2}$ concentrations in summer periods
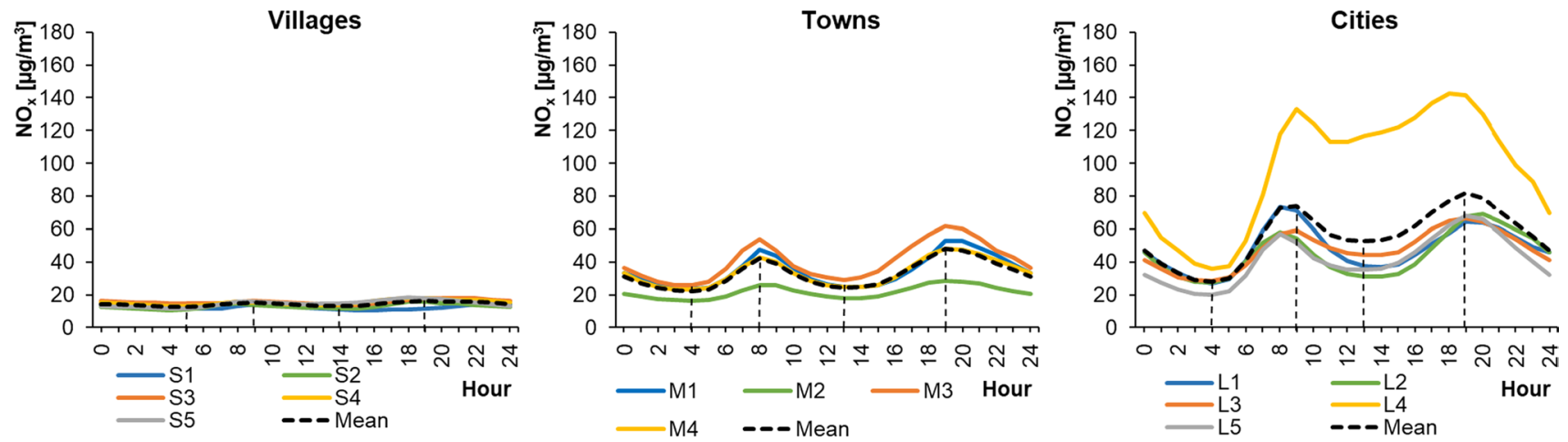

Fig. 4 Average hourly $\mathrm{NO}_{\mathrm{x}}$ concentrations in winter periods

than in WPs in the cities and towns. Similar results were previously reported (Schneider et al. 2016; Garcia et al. 2014; Martinello et al. 2014).

The average hourly $\mathrm{O}_{3}$ concentrations in WPs ranged from 20.02 to $41.23 \mu \mathrm{g} \mathrm{m}^{-3}$ in cities, from 22.62 to $48.73 \mu \mathrm{g} \mathrm{m}^{-3}$ in towns, and from 25.98 to $52.10 \mu \mathrm{g} \mathrm{m}^{-3}$ in rural areas (Fig. 6). The concentrations were higher in SPs, ranging from 29.98 to $92.27 \mu \mathrm{g} \mathrm{m}^{-3}$ in cities, from 21.61 to $94.67 \mathrm{\mu g} \mathrm{m}^{-3}$ in towns, and from 21.46 to $96.08 \mu \mathrm{g} \mathrm{m}^{-3}$ in rural areas (Fig. 7). Ground-level ozone concentrations generally increased as the size of the settlement unit decreased. This confirms the results of previous scientific studies (Guerreiro et al. 2010; Hagenbjörk et al. 2017), which showed that the level of $\mathrm{O}_{3}$ decreases as the NO concentration in the air rises. The NO level was usually higher in those areas with heavier traffic. However, the lowest $\mathrm{O}_{3}$ concentrations in SPs occurred in cities and were higher than the minimal values in towns and villages. Daily fluctuations in $\mathrm{O}_{3}$ levels were the widest in rural areas. This contradicts research into ground-level ozone concentrations 

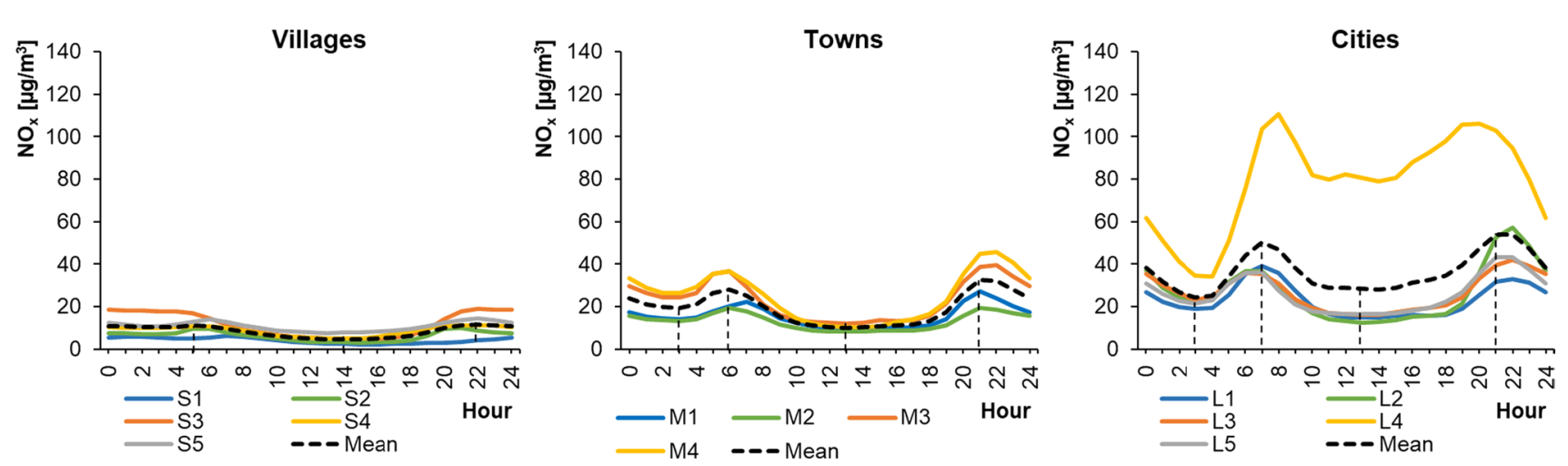

Fig. 5 Average hourly $\mathrm{NO}_{\mathrm{x}}$ concentrations in summer periods
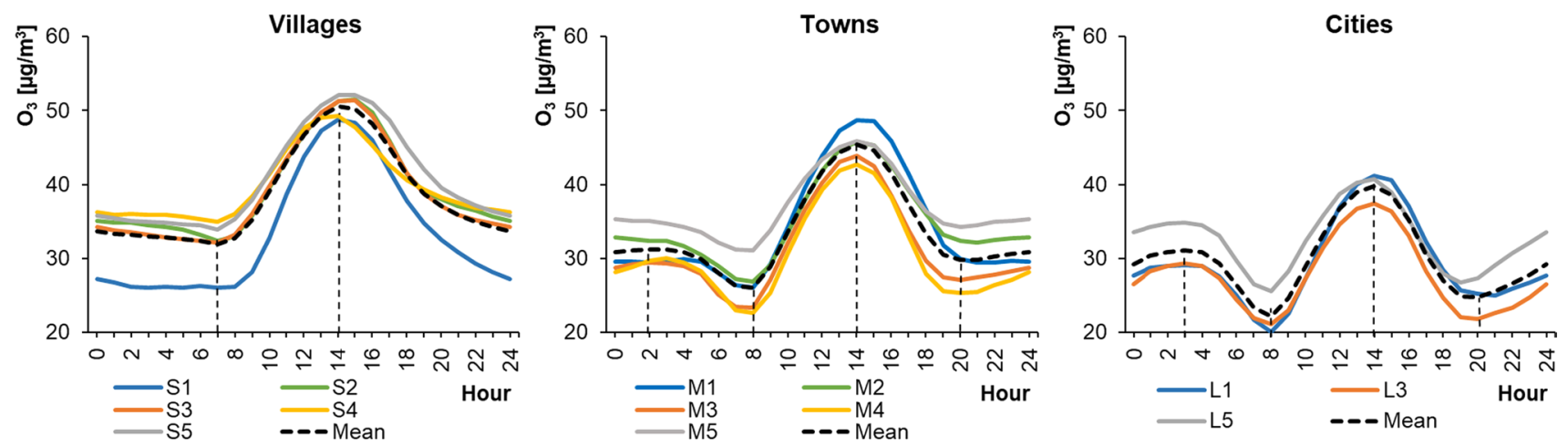

Fig. 6 Average hourly $\mathrm{O}_{3}$ concentrations in winter periods
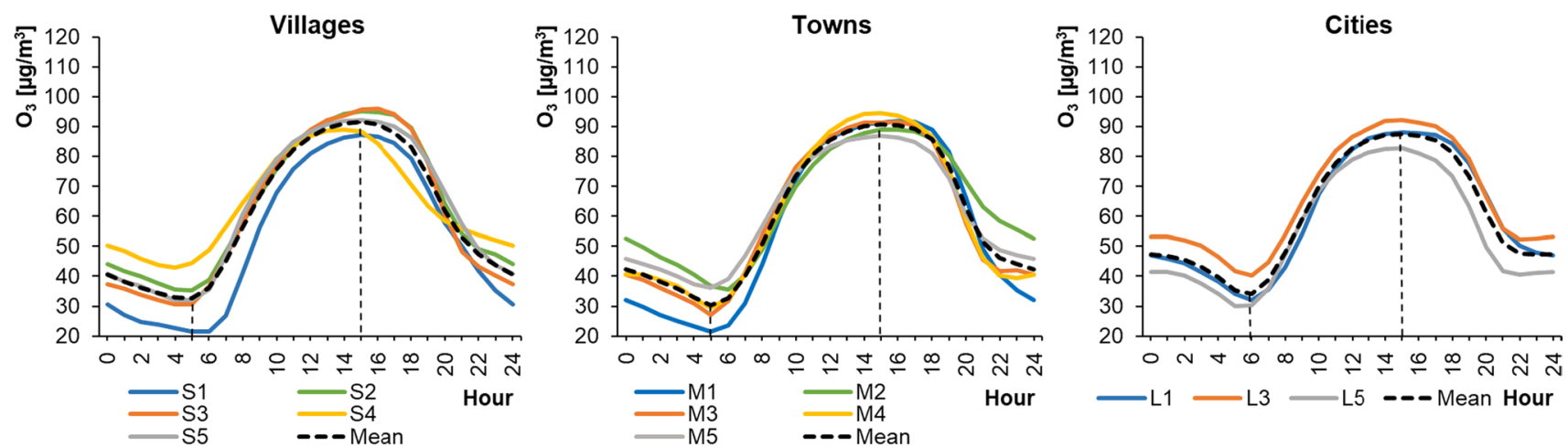

Fig. 7 Average hourly $\mathrm{O}_{3}$ concentrations in summer periods

in different types of area carried out by Zheng et al. (2010), who reported smaller ozone changes in villages than in cities. The shapes of the ozone profiles were similar for particular types of settlement unit. The daily profiles for $\mathrm{O}_{3}$ concentrations were similar to a bimodal distribution in the case of towns and cities, and unimodal for the villages. The maximum values occurred, irrespective of the season and the size of the city/village, at around 14:00-15:00 local time.
The sudden drop in $\mathrm{O}_{3}$ concentration was more significant in the case of larger settlement units and occurred at 7:00-8:00 (local time) in WPs and around 5:00 (local time) in SPs. This could be related to the decrease in the level of ozone, which reacted with nitrogen oxide emitted during the morning rush hours. The shape of the $\mathrm{O}_{3}$ diurnal profile in cities during winter is puzzling, because the level of ozone at night 
increased and at around 3:00 (local time) reached almost 3/4 of the maximum daily value.

The average hourly $\mathrm{SO}_{2}$ concentrations in WPs ranged from 4.36 to $21.27 \mu \mathrm{g} \mathrm{m}^{-3}$ in cities, from 4.84 to $23.29 \mu \mathrm{g} \mathrm{m}^{-3}$ in towns, and from 3.28 to $7.74 \mu \mathrm{g} \mathrm{m}^{-3}$ in rural areas (Fig. 8). The concentrations were much lower in SPs, ranging from 1.30 to $8.12 \mu \mathrm{g} \mathrm{m}^{-3}$ in cities, from 2.11 to $5.65 \mu \mathrm{g} \mathrm{m}^{-3}$ in towns, and from 1.40 to $5.19 \mu \mathrm{g} \mathrm{m}^{-3}$ in rural areas (Fig. 9). The level of $\mathrm{SO}_{2}$ was generally the lowest in villages and higher in towns and cities. In the Greater Poland and Lublin regions, the concentrations of sulphur dioxide in the cities of Poznań (L2) and Lublin (L5) were lower and comparable to those occurring in the towns of Piaski (S2) and Biały Stup (S5). The highest $\mathrm{SO}_{2}$ level occurred in the Łódź region (Gajew/S3, Piotrków Trybunalski/M3, and in Łódź/L3), where there is a very extensive network of power stations. Therefore, it was assumed that changes in $\mathrm{SO}_{2}$ concentrations were related to industrial power production in SPs and to emissions from the combustion of fuels for heating individual buildings in WPs. The shapes of the $\mathrm{SO}_{2}$ daily profiles were similar to unimodal (in SPs) or bimodal (in WPs) distributions. The unimodal character of the profiles was more pronounced in SPs than in WPs, with a peak around 10:00 local time.

Of the 15 selected monitoring stations, 8 measured $\mathrm{CO}$ concentrations in the ambient air. These were located mainly in cities. Unfortunately, there were no CO measuring devices installed at the other 7 stations, located in smaller settlement units. The average hourly CO concentrations in WPs ranged from 0.33 to $0.99 \mathrm{mg} \mathrm{m}^{-3}$ in cities, from 0.29 to $1.03 \mathrm{mg} \mathrm{m}^{-3}$ in towns, and from 0.33 to $0.44 \mathrm{mg} \mathrm{m}^{-3}$ in rural areas (Fig. 10). The concentrations were lower in SPs, ranging from 0.17 to $0.61 \mathrm{mg} \mathrm{m}^{-3}$ in cities, from 0.17 to $0.51 \mathrm{mg} \mathrm{m}^{-3}$ in towns, and from 0.20 to $0.24 \mathrm{mg} \mathrm{m}^{-3}$ in rural areas (Fig. 11). The CO level in the countryside changed only slightly during the day, in contrast to the fluctuations observed in towns and cities. The $\mathrm{CO}$ profiles were similar to a bimodal distribution and comparable to the $\mathrm{NO}_{2}$ daily profiles. The highest peak in $\mathrm{CO}$ concentrations was in the evening, at 20:00-22:00 (local time), in both WP and SP.

Of the 15 selected monitoring stations, 10 measured $\mathrm{PM}_{10}$ concentrations in the ambient air. These were mainly located in cities. Unfortunately, there were no $\mathrm{PM}_{10}$ measuring devices installed at the other 5 stations, located in smaller settlement units. The average hourly $\mathrm{PM}_{10}$
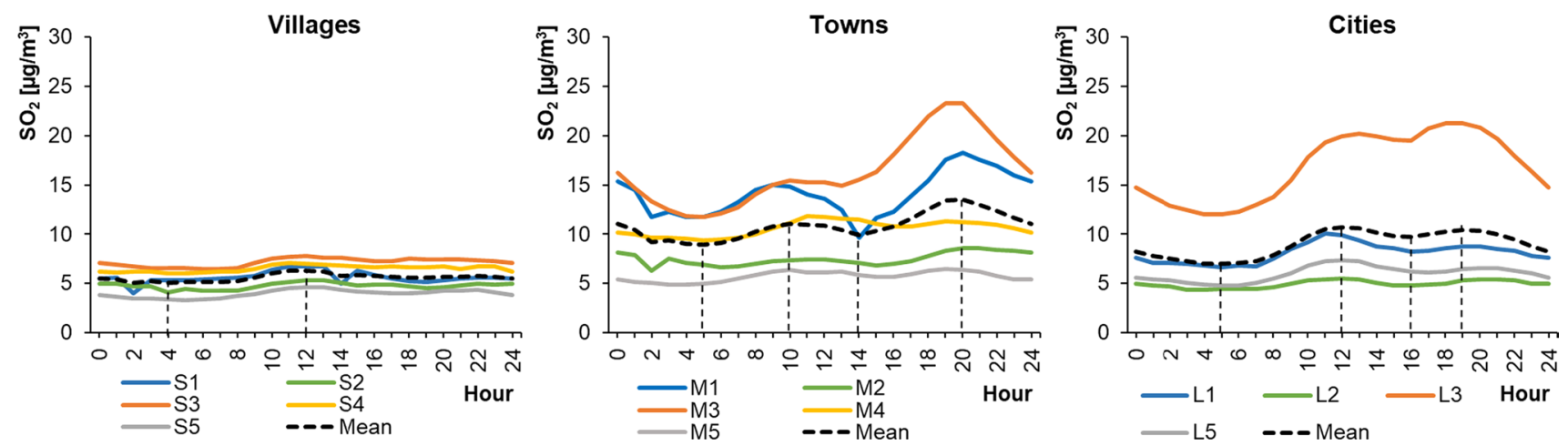

Fig. 8 Average hourly $\mathrm{SO}_{2}$ concentrations in winter periods
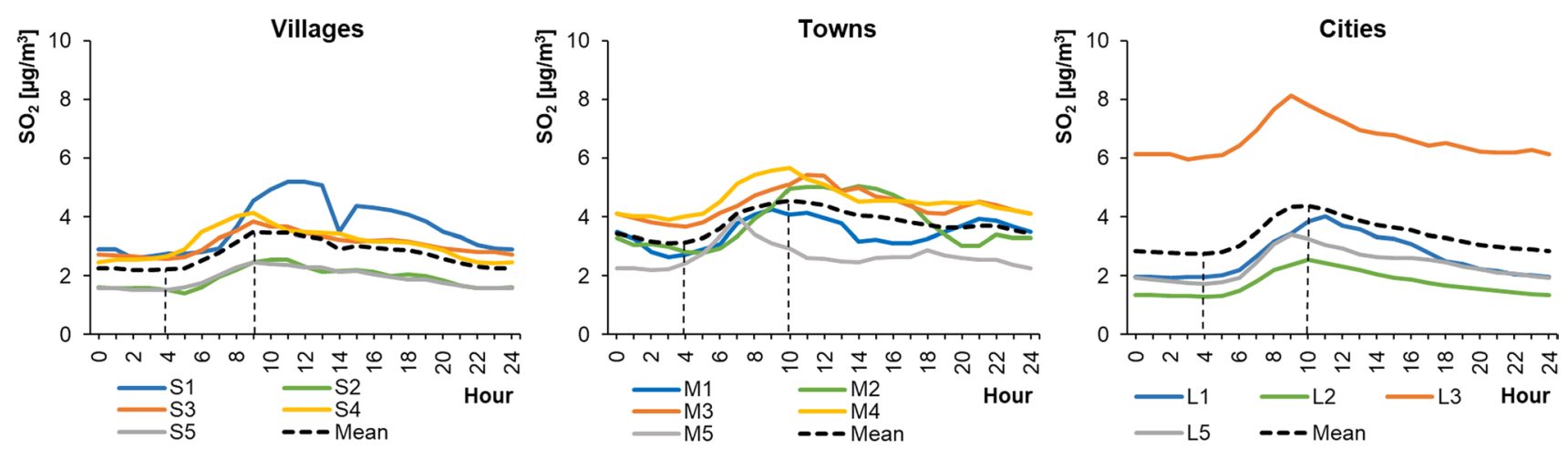

Fig. 9 Average hourly $\mathrm{SO}_{2}$ concentrations in summer periods 
concentrations in WPs ranged from 28.76 to $62.54 \mu \mathrm{g} \mathrm{m}^{-3}$ in cities, from 31.00 to $75.87 \mu \mathrm{g} \mathrm{m}^{-3}$ in towns, and from 25.07 to $43.16 \mu \mathrm{g} \mathrm{m}^{-3}$ in rural areas (Fig. 12). The concentrations in SPs ranged from 17.08 to $35.63 \mu \mathrm{g} \mathrm{m}^{-3}$ in cities, from 16.09 to $34.00 \mu \mathrm{g} \mathrm{m}^{-3}$ in towns, and from 15.90 to $28.78 \mu \mathrm{g} \mathrm{m}^{-3}$ in rural areas (Fig. 13). Therefore, during WPs the $\mathrm{PM}_{10}$ levels in towns and cities were similar. In villages, they were approximately $50 \%$ lower. The
$\mathrm{PM}_{10}$ profiles at each location were characterized by a bimodal distribution but with different shapes. The highest $\mathrm{PM}_{10}$ concentrations during WPs occurred in the evening. This was in contrast to during SPs, when some locations (Wrocław/L1, Warsaw/L4, Konin/M2, and Gajew/S3) saw their highest $\mathrm{PM}_{10}$ concentrations in the morning, around 6:00-8:00 (local time). In others (Poznań/L2, Łódź/L3, Lublin/L5, Kłodzko/M1, Piotrków Trybunalski/M3, and
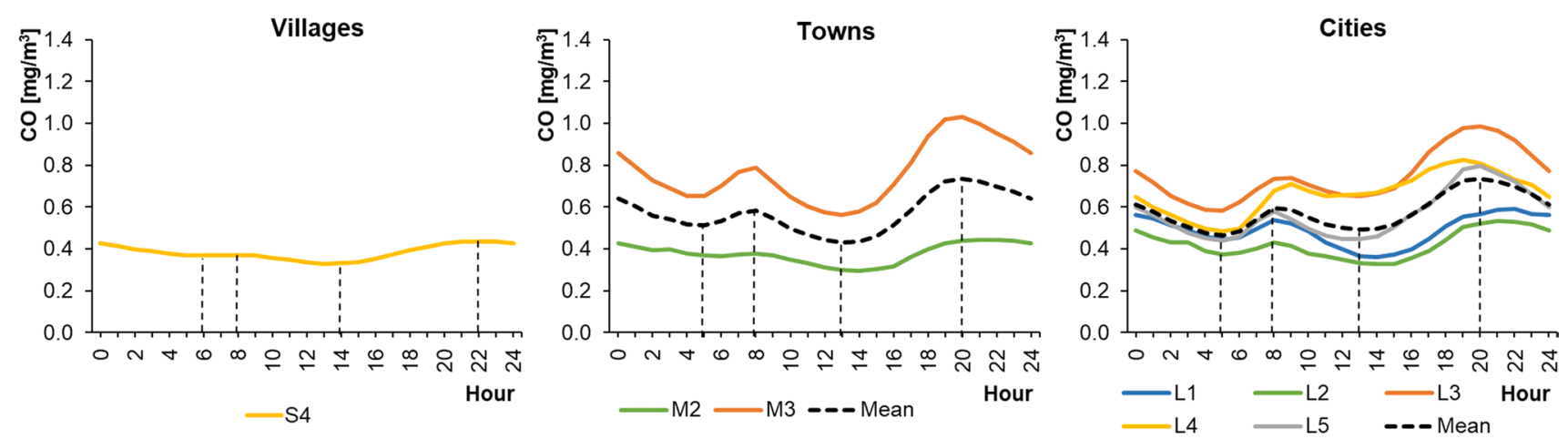

Fig. 10 Average hourly CO concentrations in winter periods
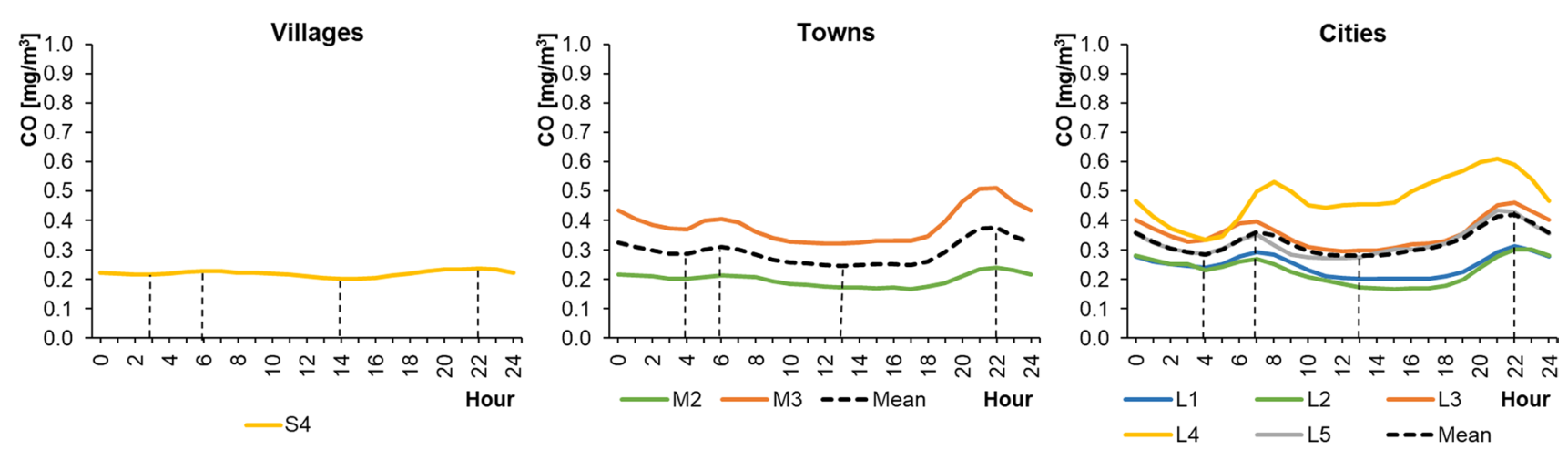

Fig. 11 Average hourly $\mathrm{CO}$ concentrations in summer periods
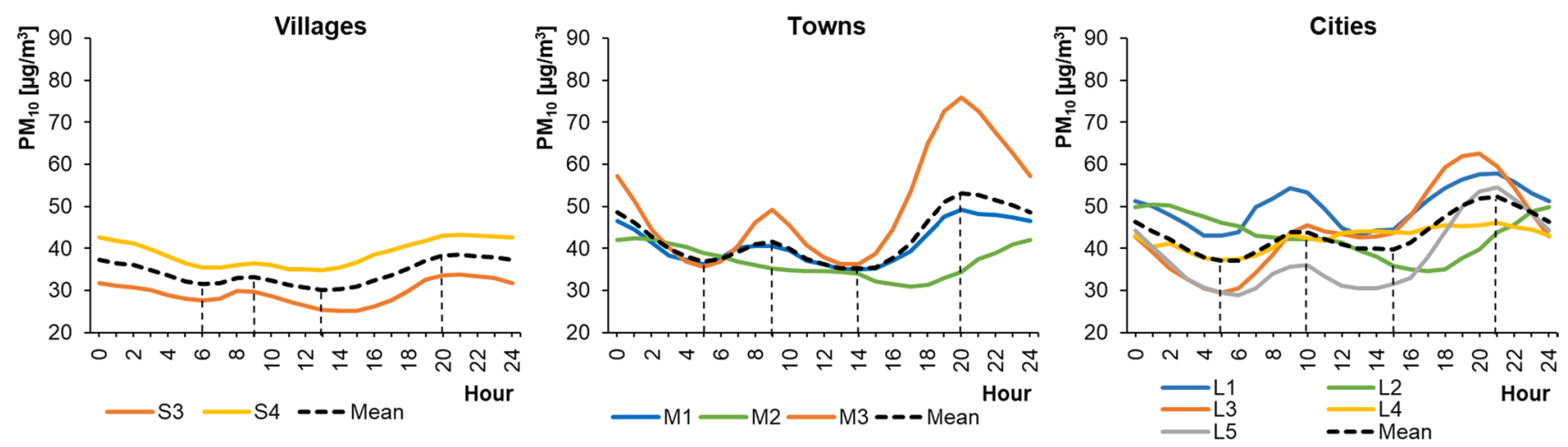

Fig. 12 Average hourly $\mathrm{PM}_{10}$ concentrations in winter periods 

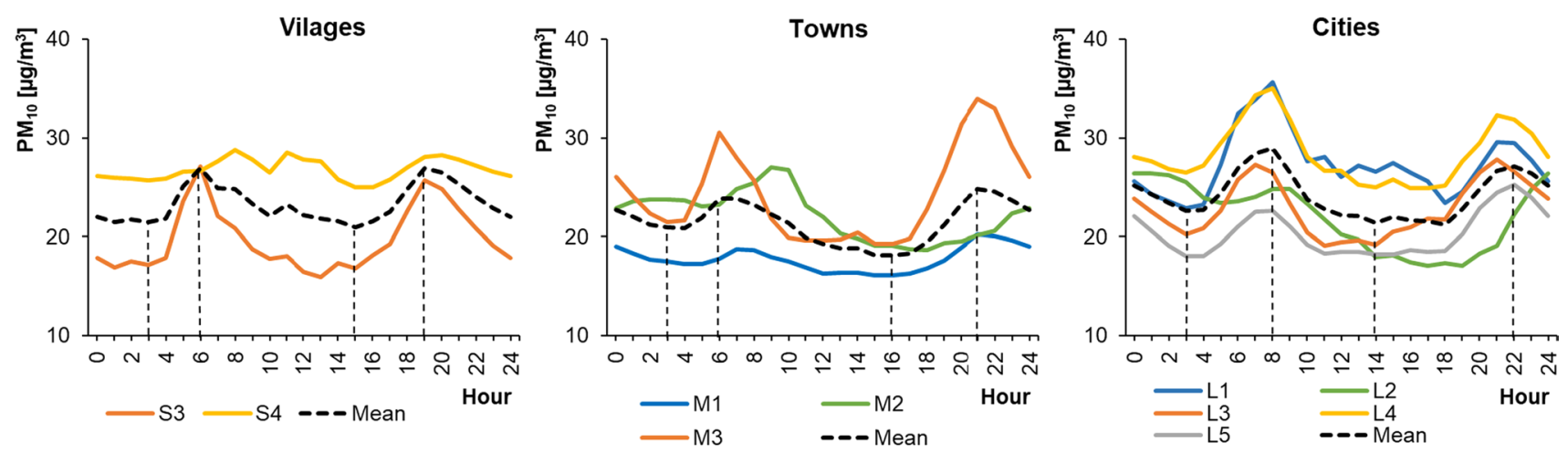

Fig. 13 Average hourly $\mathrm{PM}_{10}$ concentrations in summer periods

Belsk Duży/S4), the highest peak occurred in the evening at 21:00-22:00 (local time).

In the Polish air quality monitoring system, only $\mathrm{CB}$ stations measure $\mathrm{PM}_{2.5}$ and benzene concentrations in the ambient air. The average hourly concentrations of $\mathrm{PM}_{2.5}$ in cities differed significantly depending on the season, ranging from 23.24 to $46.42 \mu \mathrm{g} \mathrm{m}^{-3}$ in WPs and from 8.40 to $18.18 \mu \mathrm{g} \mathrm{m}^{-3}$ in SPs (Fig. 14). The concentrations in SPs were approximately three times smaller than during WPs and were lowest from 10:00 to 18:00 local time (depending on the location). The maximum values during WPs occurred in the evening at approximately 21:00 (local time). In SPs, the peak hours occurred between 6:00 and 24:00 local time. Interestingly, there were high concentrations of $\mathrm{PM}_{2.5}$ throughout the night in SPs. Previous research on the composition of dust in urban areas of Barcelona, Spain (Pérez et al. 2010) had also indicated the presence of large amounts of organic matter, molecular carbon, and aerosols in $\mathrm{PM}_{1-2.5}$ (approximately $48 \%$ of mass) and in $\mathrm{PM}_{1}$ (around 85\%) in urban ambient air. While in $\mathrm{PM}_{2.5-10}$ it contributed only to $24 \%$. This is puzzling, because sources of anthropogenic emissions are inactive at night during summer months. Therefore, it can be assumed that the increase of $\mathrm{PM}_{2.5}$ concentrations at night might be associated with the condensation of water vapor and the coagulation of fine dust particles (Pérez et al. 2010). However, in the study of air quality in Thessaloniki, Greece (Vouitsis et al. 2015), the concentrations of particle number (PNC), $\mathrm{PM}_{2.5}$, and $\mathrm{PM}_{10}$, increased during the night (with peak at 23:00-24:00) mostly in the winter period in traffic-affected sites, whereas in city-background locations this was not clearly noticeable. On the other hand, in this analysis, $\mathrm{PM}_{2.5}$ concentration decreased at night in winter, until around 3:00 local time. The differences in the shapes of the profiles and peak hours for $\mathrm{PM}_{10}$ and $\mathrm{PM}_{2.5}$ also were interesting. The diurnal variations in $\mathrm{PM}_{10}$ concentration took various shapes in cities, whereas the concentrations of $\mathrm{PM}_{2.5}$ followed very similar patterns. In addition, $\mathrm{PM}_{2.5}$ concentrations in the morning peak occurred $2 \mathrm{~h}$ earlier than the $\mathrm{PM}_{10}$ peak hours. In the study by Pérez et al. (2010), at weekdays the peaks in PM1 and PM1-2.5 occurred at 6:00-9:00, whereas peak in $\mathrm{PM}_{2.5-10}$ occurred at 10:00-15:00. At weekends, it was around 2:00-8:00 and 11:00-12:00, respectively. However, in the case of traffic-affected site in the center of Madrid, Spain, the peaks in $\mathrm{PM}_{2.5}$ and $\mathrm{PM}_{10}$ were very close to each other $( \pm 0.5 \mathrm{~h})$ and occurred at 8:00-9:00 and 20:00-21:00 (Moreno et al. 2013). Also, in urban areas, the average $\mathrm{PM}_{2.5}$ concentration are usually strongly correlated $\left(\mathrm{R}^{2}>0.80\right)$ to
Fig. 14 Average hourly $\mathrm{PM}_{2.5}$ concentrations in cities
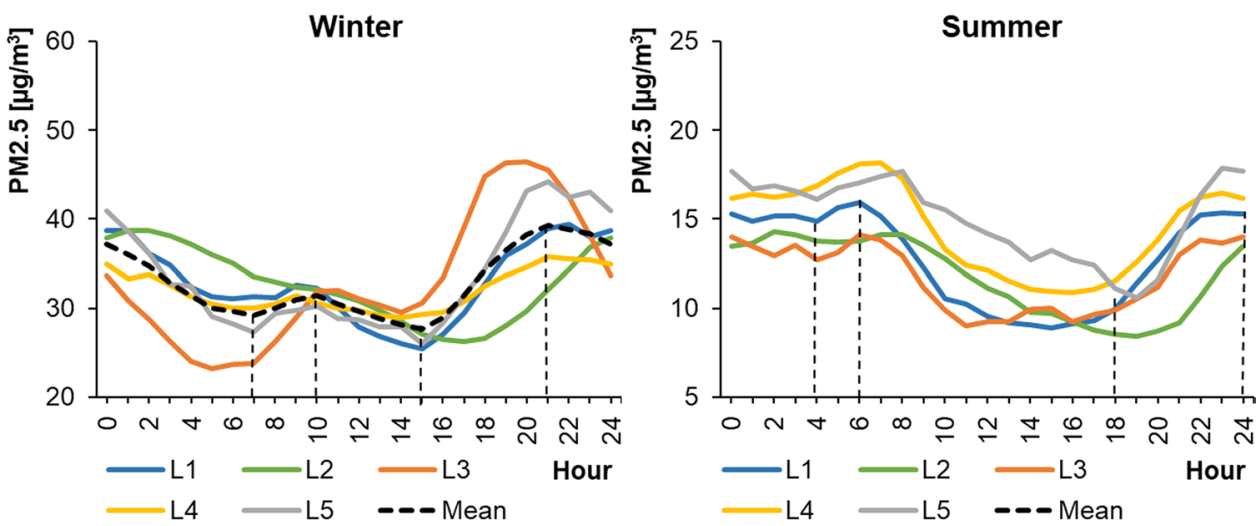
$\mathrm{PM}_{10}$ and amounted to $60-90 \%$ of $\mathrm{PM}_{10}$ concentrations (Gupta et al. 2006; Pérez et al. 2010). Nevertheless, observations of PM could indicate that differences in the varying concentrations of course and finer particles in the urban environment might be partially due to the different processes of their formation (Pérez et al. 2010).

As in the case of $\mathrm{PM}_{2.5}$, the concentrations of benzene $\left(\mathrm{C}_{6} \mathrm{H}_{6}\right)$ in cities changed and varied significantly depending on the season. The average hourly benzene concentrations ranged from 0.48 to $1.42 \mu \mathrm{g} \mathrm{m}^{-3}$ in WPs and from 1.84 to $5.47 \mu \mathrm{g} \mathrm{m}^{-3}$ in SPs (Fig. 15). The benzene level in the summer was three to four times lower than in winter. The highest concentrations always occurred in the evening, between 21:00 and 22:00 local time.

The shapes of the average daily profiles of $\mathrm{NO}_{2}$ and $\mathrm{CO}$, and $\mathrm{NO}_{\mathrm{x}}$ and $\mathrm{PM}_{10}$ were compared for different settlement units (Figs. 16, 17, 18, 19). This was to verify the generally prevailing opinion that the $\mathrm{NO}_{2}$ and $\mathrm{NO}_{\mathrm{x}}$ concentrations usually indicate road transport intensity, whereas the occurrence of $\mathrm{CO}$ and $\mathrm{PM}_{10}$ indicate emissions from road transport and area sources (so-called "low emission"). It was observed that there was a co-occurrence of changes in the concentrations,
Fig. 15 Average hourly concentrations of benzene in cities
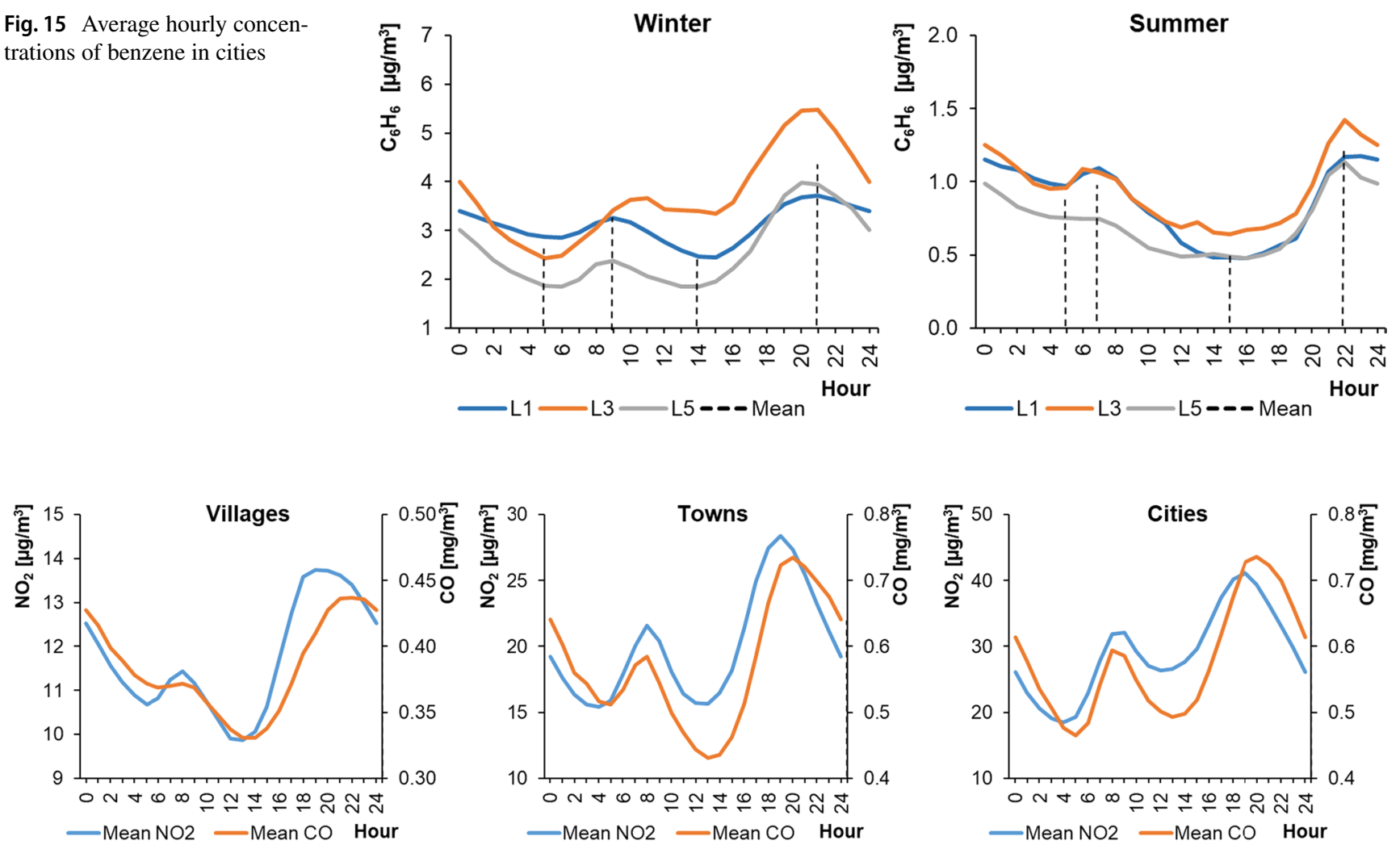

Fig. 16 Comparison of average hourly $\mathrm{NO}_{2}$ and $\mathrm{CO}$ profiles in WPs
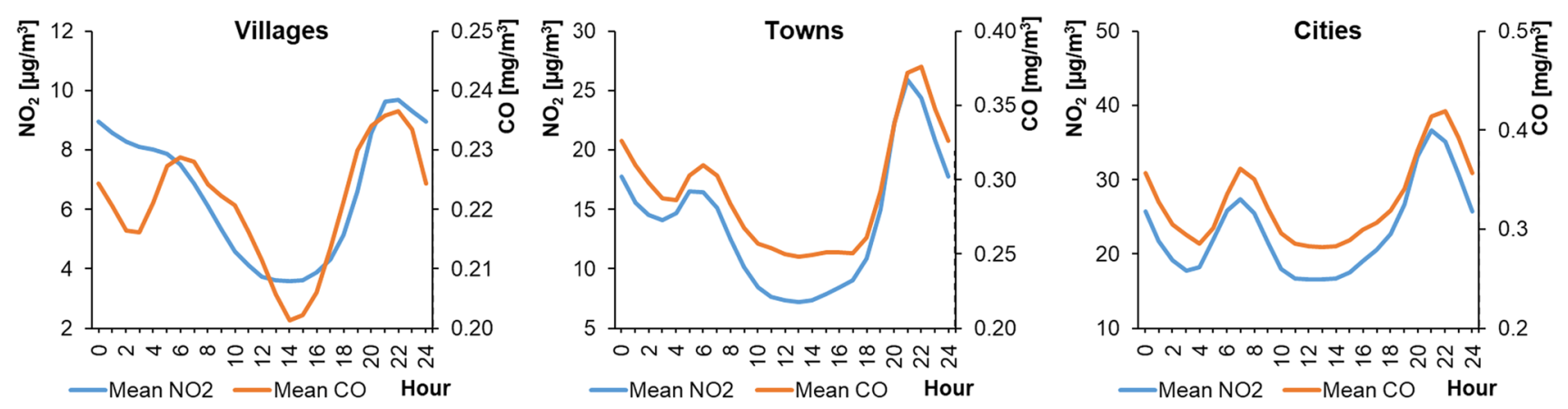

Fig. 17 Comparison of average hourly $\mathrm{NO}_{2}$ and $\mathrm{CO}$ profiles in SPs 
as well as of "peak hours" and "low hours," in both WPs and SPs. The high correspondence between the profile shapes in SPs could indicate the impact of emissions from linear sources. However, it is more difficult to explain their consistency in WPs, when there also were area emissions related to the heating of individual buildings.

The shapes of the average hourly benzene and $\mathrm{PM}_{2.5}$ profiles were compared for cities during WPs and SPs (Fig. 20). The presence of $\mathrm{PM}_{2.5}$ in the ambient air is due mainly to the burning of fossil fuels (50\% of energy in Poland is generated from hard coal and lignite, while crude oil provides $26 \%$ and natural gas $15 \%$ of the country's energy needs).
Approximately $76 \%$ of $\mathrm{PM}_{2.5}$ emissions originates from fuel combustion in power generation, industrial, and nonindustrial combustion (Dębski et al. 2015). The presence of benzene results from tobacco smoke and from burning liquid fuels in car engines (WHO 2000). Also, in the transport-affected sites, the carbonaceous compounds are substantial (35-48\%) components of $\mathrm{PM}_{2.5}$ (Gómez-Perales et al. 2004; Harrison et al. 2004, Pérez et al. 2010). In the analyzed locations, the changes in $\mathrm{PM}_{2.5}$ and benzene levels had similar hourly profiles, indicating the co-occurrence of these air pollutants in urbanized areas. The co-existence of PM and benzene (correlation coefficient of 0.69-0.97)
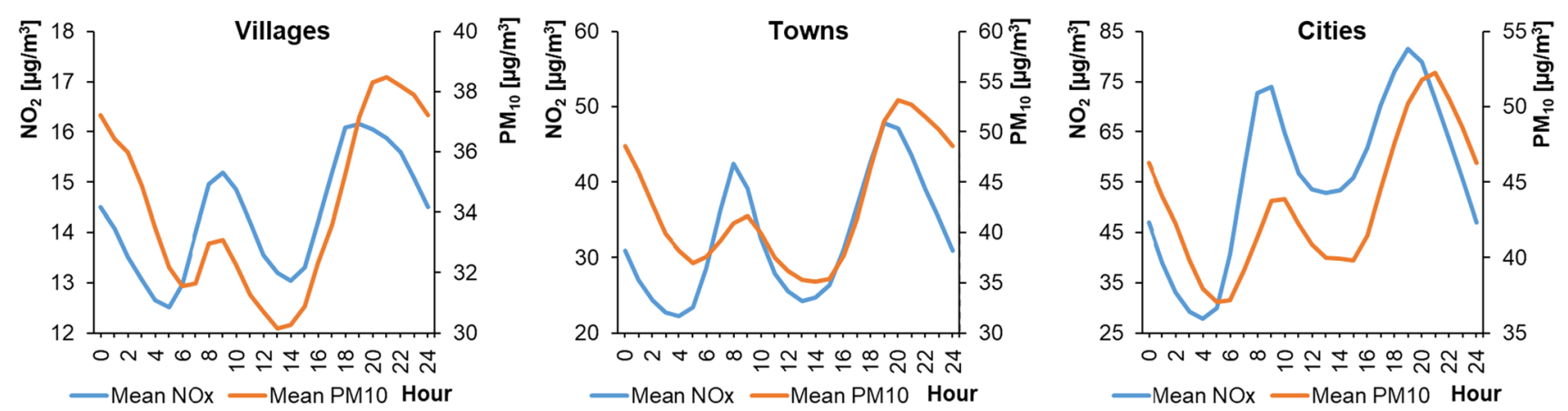

Fig. 18 Comparison of average hourly $\mathrm{NO}_{\mathrm{x}}$ and $\mathrm{PM}_{10}$ profiles in WPs
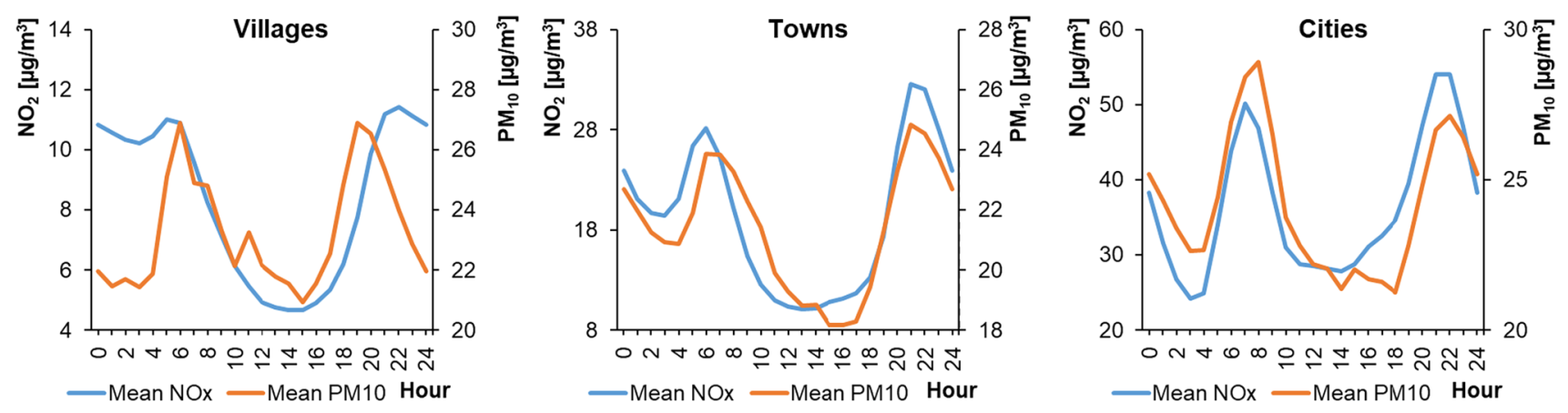

Fig. 19 Comparison of average hourly $\mathrm{NO}_{\mathrm{x}}$ and $\mathrm{PM}_{10}$ profiles in SPs

Fig. 20 Comparison of average hourly benzene and $\mathrm{PM}_{2.5}$ profiles in cities
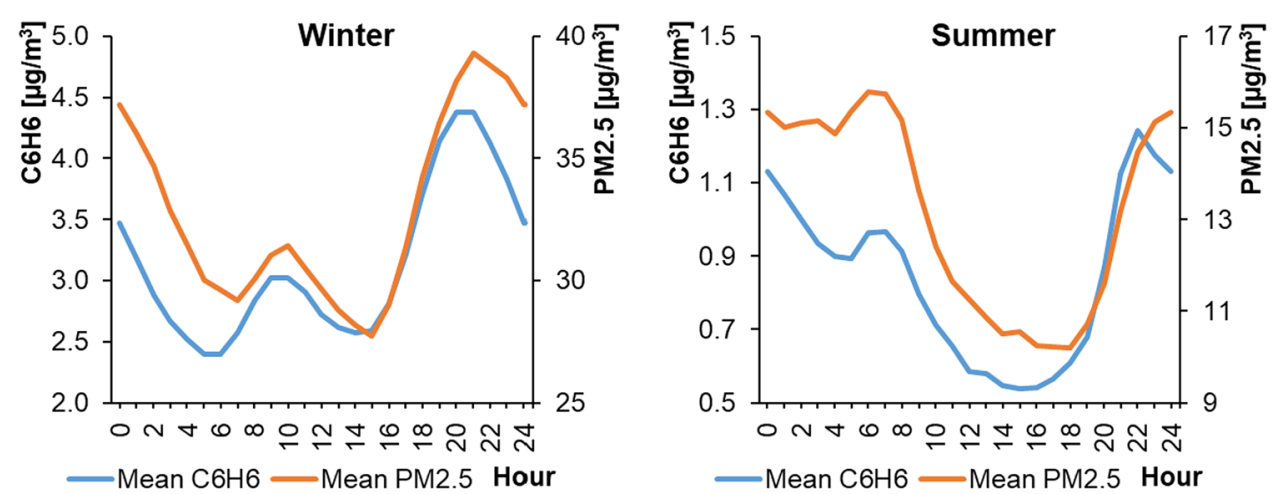
during the transport rush hours were previously reported (Gupta et al. 2006).

There were significant shifts between the occurrence of the daily maximum and daily minimum in WPs and SPs (Tables 6, 7, 8). The most favorable conditions, in terms of levels of air pollution, occurred in towns and cities in the morning at 3:00-5:00 (local time) and in the afternoon at 12:00-15:00. In the villages, the best air quality occurred between 4:00 and 6:00 (local time). On the other hand, during WPs the least favorable conditions in terms of air quality occurred, regardless of location at 8:00-10:00 and 19:00-21:00 (local hour). In SPs, air quality was poorest at the following times: 7:00-8:00 and 21:00-22:00 in cities; 5:00-6:00 and 21:00-22:00 in towns; 6:00-9:00 and 19:00-22:00 in villages. For a comparison, when considering $\mathrm{PM}$ and $\mathrm{NO}_{2}$ air contamination, in urban-traffic area in Madrid (Spain), the most favorable conditions occurred at around 4:00 and 15:00 local hour (Moreno et al. 2013). In Barcelona (Spain), this was around 15:00 (Pérez et al. 2010), and in Thessaloniki (Greece) around 4:00-6:00 and 15:00-18:00 (Vouitsis et al. 2015). For comparison, in the cities of Canoas and Esteio, in Brazil, the most favorable air quality conditions occurred at 4:00-6:00 and 14:00-17:00 (Agudelo-Castaneda and Teixeira 2014).
Table 6 Daily maximum and daily minimum average concentrations of air pollutants in cities (CB stations)
Table 7 Daily maximum and daily minimum average concentrations of air pollutants in cities (TB stations)

\begin{tabular}{|c|c|c|c|c|c|c|c|c|}
\hline & \multicolumn{4}{|c|}{ Peak hours } & \multicolumn{4}{|c|}{ Low hours } \\
\hline & \multicolumn{2}{|c|}{ Winter period } & \multicolumn{2}{|c|}{ Summer period } & \multicolumn{2}{|c|}{ Winter period } & \multicolumn{2}{|c|}{ Summer period } \\
\hline & Morning & Evening & Morning & Evening & Morning & Evening & Morning & Evening \\
\hline $\mathrm{NO}_{2}$ & 09:00 & 19:00 & 07:00 & $21: 00$ & 04:00 & $12: 00$ & 03:00 & $12: 00$ \\
\hline $\mathrm{NO}_{\mathrm{x}}$ & 09:00 & 19:00 & 07:00 & 21:00 & 04:00 & 13:00 & 03:00 & $13: 00$ \\
\hline $\mathrm{O}_{3}$ & 03:00 & $14: 00$ & $\mathrm{n} / \mathrm{a}$ & $15: 00$ & 08:00 & 20:00 & 06:00 & $\mathrm{n} / \mathrm{a}$ \\
\hline $\mathrm{SO}_{2}$ & $12: 00$ & 19:00 & $10: 00$ & $\mathrm{n} / \mathrm{a}$ & 05:00 & $16: 00$ & 04:00 & $\mathrm{n} / \mathrm{a}$ \\
\hline $\mathrm{CO}$ & 08:00 & 20:00 & 07:00 & $22: 00$ & 05:00 & $13: 00$ & 04:00 & $13: 00$ \\
\hline $\mathrm{PM}_{10}$ & $10: 00$ & 21:00 & 08:00 & $22: 00$ & 03:00 & $14: 00$ & 03:00 & $14: 00$ \\
\hline $\mathrm{PM}_{2.5}$ & 07:00 & 21:00 & 06:00 & $24: 00$ & 03:00 & $12: 00$ & 04:00 & $18: 00$ \\
\hline $\mathrm{C}_{6} \mathrm{H}_{6}$ & 09:00 & 21:00 & 07:00 & $22: 00$ & 05:00 & $14: 00$ & 05:00 & $15: 00$ \\
\hline
\end{tabular}

\begin{tabular}{|c|c|c|c|c|c|c|c|c|}
\hline & \multicolumn{4}{|c|}{ Peak hours } & \multicolumn{4}{|c|}{ Low hours } \\
\hline & \multicolumn{2}{|c|}{ Winter period } & \multicolumn{2}{|c|}{ Summer period } & \multicolumn{2}{|c|}{ Winter period } & \multicolumn{2}{|c|}{ Summer period } \\
\hline & Morning & Evening & Morning & Evening & Morning & Evening & Morning & Evening \\
\hline $\mathrm{NO}_{2}$ & 08:00 & $19: 00$ & $05: 00$ & $21: 00$ & 04:00 & $13: 00$ & 03:00 & $12: 00$ \\
\hline $\mathrm{NO}_{\mathrm{x}}$ & 08:00 & $19: 00$ & 06:00 & $21: 00$ & 04:00 & $13: 00$ & 03:00 & $13: 00$ \\
\hline $\mathrm{O}_{3}$ & 02:00 & $14: 00$ & $\mathrm{n} / \mathrm{a}$ & $15: 00$ & 08:00 & $20: 00$ & 05:00 & $\mathrm{n} / \mathrm{a}$ \\
\hline $\mathrm{SO}_{2}$ & $10: 00$ & $20: 00$ & $10: 00$ & $\mathrm{n} / \mathrm{a}$ & 05:00 & $14: 00$ & 04:00 & $\mathrm{n} / \mathrm{a}$ \\
\hline $\mathrm{CO}$ & 08:00 & $20: 00$ & $06: 00$ & $22: 00$ & $05: 00$ & $13: 00$ & 04:00 & $13: 00$ \\
\hline $\mathrm{PM}_{10}$ & 09:00 & 20:00 & 06:00 & $21: 00$ & 05:00 & $14: 00$ & 03:00 & $16: 00$ \\
\hline
\end{tabular}

Table 8 Daily maximum and daily minimum average concentrations of air pollutants in villages ( $\mathrm{RB}$ stations)

\begin{tabular}{|c|c|c|c|c|c|c|c|c|}
\hline & \multicolumn{4}{|c|}{ Peak hours } & \multicolumn{4}{|c|}{ Low hours } \\
\hline & \multicolumn{2}{|c|}{ Winter period } & \multicolumn{2}{|c|}{ Summer period } & \multicolumn{2}{|c|}{ Winter period } & \multicolumn{2}{|c|}{ Summer period } \\
\hline & Morning & Evening & Morning & Evening & Morning & Evening & Morning & Evening \\
\hline $\mathrm{NO}_{2}$ & 08:00 & 19:00 & $\mathrm{n} / \mathrm{a}$ & $22: 00$ & $05: 00$ & 13:00 & $\mathrm{n} / \mathrm{a}$ & 13:00 \\
\hline $\mathrm{NO}_{\mathrm{x}}$ & 09:00 & $19: 00$ & 07:00 & $21: 00$ & 04:00 & $13: 00$ & 03:00 & $13: 00$ \\
\hline $\mathrm{O}_{3}$ & $\mathrm{n} / \mathrm{a}$ & $14: 00$ & $\mathrm{n} / \mathrm{a}$ & $15: 00$ & 07:00 & $\mathrm{n} / \mathrm{a}$ & 05:00 & $\mathrm{n} / \mathrm{a}$ \\
\hline $\mathrm{SO}_{2}$ & $\mathrm{n} / \mathrm{a}$ & $12: 00$ & 09:00 & $\mathrm{n} / \mathrm{a}$ & 04:00 & $\mathrm{n} / \mathrm{a}$ & 04:00 & $\mathrm{n} / \mathrm{a}$ \\
\hline $\mathrm{CO}$ & 08:00 & $22: 00$ & 06:00 & $22: 00$ & 06:00 & $14: 00$ & 03:00 & $14: 00$ \\
\hline $\mathrm{PM}_{10}$ & 09:00 & 20:00 & 06:00 & 19:00 & 06:00 & 13:00 & 03:00 & $15: 00$ \\
\hline
\end{tabular}


According to the literature (Gaffron 2012; Menut et al. 2012; Moreno et al. 2013; Pérez et al. 2010; Vouitsis et al. 2015), daily variations in $\mathrm{NO}_{2}$ and $\mathrm{PM}_{10}$ concentrations show a shift between peak hours during road transport rush hours (Table 9). In selected locations in Central Europe, shifts of $\pm 3 \mathrm{~h}$ have been reported in the morning and of up to $+5 \mathrm{~h}$ in the evening. In cities of South-Western Europe, this shift reached up to $+4 \mathrm{~h}$ in both the morning and in the evening. In the city of Thessaloniki (Greece) in SouthEastern Europe, there was a shift of $\pm 4 \mathrm{~h}$ in the morning and $0-3 \mathrm{~h}$ in the evening. Therefore, the "most and least favorable" ambient air-quality conditions were not strictly related/correlated to road traffic intensity in cities, towns, and villages. However, the "time shift" between emissions and increases/decreases in air pollutant concentrations could be the result of meteorological factors, which may (or may not) result in dispersal processes and coagulation, as well as in chemical and photochemical processes.

\section{Conclusions}

The purpose of this investigation was to determine the "most" and "least favorable" hours during the day in terms of ambient air quality for different types of settlement unit (cities, towns, and villages). The results could be used to
Table 9 Differences between the occurrence of maximum average hourly $\mathrm{NO}_{2}$ and $\mathrm{PM}_{10}$ concentrations and traffic rush hours (described as "traffic" stations)

\begin{tabular}{|c|c|c|c|c|c|}
\hline \multicolumn{2}{|l|}{ Location, station type } & $\begin{array}{l}\text { Peak hour/ } \\
\text { difference } \\
\text { (h) }\end{array}$ & $\begin{array}{l}\text { Peak hour/ } \\
\text { difference } \\
\text { (h) }\end{array}$ & Source & Description/period \\
\hline \multicolumn{6}{|l|}{ Central Europe } \\
\hline Hamburg & Traffic & 08:00/- & $17: 00 /-$ & Gaffron (2012) & Year \\
\hline \multirow[t]{2}{*}{ Warsaw, CB } & $\mathrm{NO}_{2}$ & - & $22: 00 /+5$ & Menut et al. (2012) & Model, summer \\
\hline & $\mathrm{PM}_{10}$ & $06: 00 /-2$ & $22: 00 /+5$ & & \\
\hline \multirow[t]{4}{*}{ Poland, CB } & $\mathrm{NO}_{2}$ & $09: 00 /+1$ & $19: 00 /+2$ & Own analysis & Winter \\
\hline & $\mathrm{PM}_{10}$ & $10: 00 /+2$ & $21: 00 /+4$ & & \\
\hline & $\mathrm{NO}_{2}$ & $07: 00 /-1$ & $21: 00 /+4$ & & Summer \\
\hline & $\mathrm{PM}_{10}$ & $08: 00 /+0$ & $22: 00 /+5$ & & \\
\hline \multirow[t]{4}{*}{ Poland, TB } & $\mathrm{NO}_{2}$ & $08: 00 /+0$ & $19: 00 /+2$ & & Winter \\
\hline & $\mathrm{PM}_{10}$ & $09: 00 /+1$ & $21: 00 /+4$ & & \\
\hline & $\mathrm{NO}_{2}$ & $05: 00 /-3$ & $21: 00 /+4$ & & Summer \\
\hline & $\mathrm{PM}_{10}$ & $06: 00 /-2$ & $21: 00 /+4$ & & \\
\hline \multirow[t]{4}{*}{ Poland, RB } & $\mathrm{NO}_{2}$ & $08: 00 /+2$ & $19: 00 /+2$ & & Winter \\
\hline & $\mathrm{PM}_{10}$ & $09: 00 /+1$ & $20: 00 /+3$ & & \\
\hline & $\mathrm{NO}_{2}$ & - & $22: 00 /+5$ & & Summer \\
\hline & $\mathrm{PM}_{10}$ & $06: 00 /-2$ & $19: 00 /+2$ & & \\
\hline \multicolumn{6}{|l|}{ South-West Europe } \\
\hline Barcelona & Traffic & 06:00/- & 17:00/- & Pérez et al. (2010) & Summer, weekdays \\
\hline \multirow[t]{4}{*}{ Barcelona,CB } & $\mathrm{NO}_{2}$ & $07 / 00 /+1$ & $21: 00 /+4$ & & Summer, weekdays \\
\hline & $\mathrm{PM}_{1}$ & $06: 00 /+0$ & $21: 00 /+4$ & & \\
\hline & $\mathrm{PM}_{1-2.5}$ & $09: 00 /+3$ & - & & \\
\hline & $\mathrm{PM}_{2.5-10}$ & $10: 00 /+4$ & $14: 00 /-3$ & & \\
\hline \multirow[t]{2}{*}{ Madrid, UT } & $\mathrm{NO}_{2}$ & $08: 00 /+2$ & $21: 00 /+4$ & Moreno et al. (2013) & Winter \\
\hline & $\mathrm{PM}_{10}$ & $09: 00 /+3$ & $20: 00 /+3$ & & \\
\hline \multicolumn{6}{|l|}{ South-East Europe } \\
\hline Thessaloniki & Traffic & 09:00/- & 21:00/- & Vouitsis et al. (2015) & Winter \\
\hline \multirow[t]{2}{*}{ Thessaloniki, CB } & $\mathrm{PM}_{10}$ & $13: 00 /+4$ & $22: 00 /+1$ & & Winter \\
\hline & $\mathrm{PM}_{10}$ & $11: 00 /+2$ & $21: 00 /+0$ & & Summer \\
\hline \multirow[t]{4}{*}{ Thessaloniki, UT } & $\mathrm{NO}_{2}$ & $13: 00 /+4$ & $21: 00 /+0$ & & Winter \\
\hline & $\mathrm{PM}_{10}$ & $11: 00 /+2$ & $24: 00 /+3$ & & \\
\hline & $\mathrm{NO}_{2}$ & $13: 00 /+4$ & $21: 00 /+0$ & & Summer \\
\hline & $\mathrm{PM}_{10}$ & $07: 00 /-2$ & $21: 00 /+0$ & & \\
\hline
\end{tabular}

Our study, based on Gaffron (2012), Menut et al. (2012), Pérez et al. (2010), Moreno et al. (2013), and Vouitsis et al. (2015)

$U T$ air quality monitoring stations located near urban traffic 
help improve air quality management process in cities, towns, and villages. The concentrations of air pollutants were found to change dynamically during the day. Each air pollutant had a unusual, characteristic daily concentration profile, resembling a unimodal or bimodal distribution. The profiles changed significantly depending on the season. The concentrations of $\mathrm{SO}_{2}, \mathrm{CO}, \mathrm{PM}_{10}, \mathrm{PM}_{2.5}$, and benzene were significantly higher in winter periods than during summer. The time between "peak hours" of air pollutant concentration during the day also was shorter in the winter.

The level of air pollutants was generally higher in the analyzed cities than in the towns and villages. Although the level of air pollution depended largely on the size of the settlement unit (city, town, or village), the daily profiles of the concentrations of air pollutants had relatively similar shapes. There were clear local maxima and minima during the day. The peak hours for air pollution usually did not coincide with the assumed traffic-intensity peaks (rush hours). This is in contrast to claims made in the literature that air pollution depends largely on road-traffic intensity (Agudelo-Castaneda and Teixeira 2014; Menut et al. 2012; Moreno et al. 2013, Pérez et al. 2010). Our analysis shows that there was a time shift of $\pm 5 \mathrm{~h}$ between the peak hours of air pollution and the transport rush hours. However, this time shift depended on the type of air pollutant, the season, and the size of the settlement unit.

Different approaches can be used to assess the daily changes in the concentration of pollution. It also is difficult to identify the most important air pollutants. The best and worst conditions in terms of ambient air quality should be determined individually for each country/region, depending on the pollutants, the climate, and the characteristics of the emission sources. Our analysis focused on high concentrations of $\mathrm{NO}_{2}, \mathrm{CO}$, dust, and benzene, which were characterized by similar shapes of average hourly changes. Less attention was given to $\mathrm{O}_{3}$ and $\mathrm{SO}_{2}$. This was due to the fact that in the temperate climate of Central Europe, the ozone concentration in summer rarely exceeds permissible standards in cities and villages. Concentrations of sulphur dioxide in such areas are nowadays also very low. In Poland, this is a consequence of the modernization of the power generation sector (Cichowicz et al. 2017, 2018). However, permissible levels were exceeded in the cases of particulate matter (Wielgosiński et al. 2018; EEA 2016), benzene, and benzo(a)pyrene (EEA 2016) during winter periods. These air pollutants are related with the burning of fossil fuels for heating individual buildings.

Our analysis indicates that during winter the highest concentrations of pollutants occurred in cities, towns and villages in the mornings at 8:00-10:00 and evenings at 19:00-21:00 (local time). In summer periods, unfavorable conditions occurred in the mornings at 5:00-9:00 and in the evenings at 21:00-22:00 (local hour). The periods of worst air quality in the various settlement units differed by $\pm 2 \mathrm{~h}$. The best ambient air-quality conditions in cities, towns, and villages, with the exception of ozone and taking into account mainly concentrations of $\mathrm{NO}_{2}$ and dust, occurred in the early mornings and in the afternoon. Therefore, the most favorable ambient air-quality conditions occurred between 3:00 and 5:00 and between 12:00 and 15:00 (local time). This information is particularly valuable for people to schedule outdoor activities, such as recreation or sport, as well as for structuring the working day (e.g., lunchtime, which usually takes place at 12:00-13:00) and time spent outside buildings. As a result, for example, children and the elderly may be recommended to engage in outdoor activities before 18:00 in urban areas during summer, because later in the day there is an increase in the concentrations of dust, $\mathrm{NO}_{2}$, and $\mathrm{CO}$. However, there is a higher concentration of ozone at this time. Thus, air quality should be assessed on a case-by-case basis, for each area/region, taking into account both the type of settlement unit, its geographical location, the climate, and the types of emission sources.

Acknowledgements The authors thank the Voivodship Inspectorates for Environmental Protection (WIOŚ) in Poland and the Chief Inspectorate for Environmental Protection (GIOŚ) in Poland for allowing the use of measurement data obtained from air quality monitoring stations.

Open Access This article is distributed under the terms of the Creative Commons Attribution 4.0 International License (http://creativeco mmons.org/licenses/by/4.0/), which permits unrestricted use, distribution, and reproduction in any medium, provided you give appropriate credit to the original author(s) and the source, provide a link to the Creative Commons license, and indicate if changes were made.

\section{References}

Agudelo-Castaneda DM, Teixeira EC (2014) Time-series analysis of surface ozone and nitrogen oxides concentrations in an urban area at Brazil. Atmos Pollut Res 5(3):411-420. https://doi.org/10.5094/ APR.2014.048

Agudelo-Castañeda DM, Teixeira EC, Schneider IL et al (2017) Exposure to polycyclic aromatic hydrocarbons in atmospheric PM1.0 of urban environments: carcinogenic and mutagenic respiratory health risk by age groups. Environ Pollut 224:158-170

Agudelo-Castañeda DM, Teixeira EC, Braga M et al (2019) Cluster analysis of urban ultrafine particles size distributions. Atmos Pollut Res 10(1):45-52

Bouhambra WS, Elkilani AS, Raheem MY (2000) Analysis of indoor concentrations of benzene using an air quality model. Arch Environ Health 55(3):201-209

Chaloulakou A, Mavroidis I (2002) Comparison of indoor and outdoor concentrations of $\mathrm{CO}$ at a public school. Evaluation of an indoor air quality model. Atmos Environ 36(11):1769-1781. https://doi. org/10.1016/s1352-2310(02)00151-6

Cichowicz R (2018) Spatial distribution of pollutants in the area of the former CHP plant. In: E3S web of conferences, vol 28, p 01007. https://doi.org/10.1051/e3sconf/20182801007

Cichowicz R, Stelęgowski A (2018a) Effect of thermal sludge processing on selected components of air quality in the vicinity of a 
wastewater treatment plant. Chem Papers. https://doi.org/10.1007/ s11696-018-0636-y

Cichowicz R, Stelęgowski A (2018b) The distribution of air temperature and velocity in the selected boiler room. In: E3S web of science, vol 44, p 00020. https://doi.org/10.1051/e3sconf/20184 400020

Cichowicz R, Stelęgowski A (2018c) Selected air pollutants in urban and rural areas, under the influence of power plants. Acta Innovations 29:41-52. https://doi.org/10.32933/ActaInnovations.29.5

Cichowicz R, Wielgosiński G, Targaszewska A (2016) Analysis of $\mathrm{CO}_{2}$ concentration distribution inside and outside small boiler plants. Ecol Chem Eng S 23(1):49-60. https://doi.org/10.1515/ eces-2016-0003

Cichowicz R, Wielgosiński G, Fetter W (2017) Dispersion of atmospheric air pollution in summer and winter season. Environ Monitor Assess 12:189-605. https://doi.org/10.1007/s1066 1-017-6319-2

Colbeck I, Nasir ZA, Hasnain S, Sultan S (2008) Indoor air quality at rural and urban sites in Pakistan. Water Air Soil Pollut Focus 8(1):61-69. https://doi.org/10.1007/s11267-007-9139-5

De Paoli F, Agudelo-Castañeda DM, Teixeira EC et al (2018) Number concentrations and size distributions of nanoparticles during the use of hand tools in refurbishment activities. J Nanopart Res 20:264

Dębski B, Olecka A, Bebkiewicz K, Kargulewicz I, Rutkowski J, Zasina D, Zimakowska-Laskowska M, Żaczek M (2015) National balance of SO2, NOx, CO, NH3, NMLZO, dust, heavy metals and TZO in the SNAP and NFR classification system. Basic report. The National Centre for Emissions Management (KOBiZE), Warsaw

Dijkstra L, Poelman H (2012) Cities in Europe. The new OECD-EU definition. Brussels. Eur Commission Regional Focus Rep RF $01 / 2012$

EEA (2016) Air quality in Europe-2016 report, European Environment Agency, Publications Office of the European Union, Luxembourg

Feng J, Zhong M, Xu B et al (2014) Concentrations, seasonal and diurnal variations of black carbon in $\mathrm{PM}_{2.5}$ in Shanghai, China. Atmos Res 147:1-9. https://doi.org/10.1016/j.atmosres.2014.04.018

Fenger J (1999) Urban air quality. Atmos Environ 33(29):4877-4900. https://doi.org/10.1016/S1352-2310(99)00290-3

Gaffron P (2012) Urban transport, environmental justice and human daily activity patterns. Transp Policy 20:114-127. https://doi. org/10.1016/j.tranpol.2012.01.011

Garcia KO, Teixeira EC, Agudelo-Castañeda DM et al (2014) Assessment of nitro-polycyclic aromatic hydrocarbons in $\mathrm{PM}_{1}$ near an area of heavy-duty traffic. Sci Total Environ 479-480:57-65

Gómez-Perales JE, Colvile RN, Nieuwenhuijsen MJ et al (2004) Commuters' exposure to $\mathrm{PM}_{2.5}, \mathrm{CO}$, and benzene in public transport in the metropolitan area of Mexico City. Atmos Environ 38(8):1219-1229

Guerreiro C, Horalek J, de Leeuw F et al (2010) Status and trends of $\mathrm{NO}_{2}$ ambient concentrations in Europe. European topic centre on air and climate change, Bilthoven. ETC/ACC Technical Paper 2010/19

Gupta AK, Nag S, Mukhopadhyay UK (2006) Characterisation of $\operatorname{PM}(10), \operatorname{PM}(2.5)$ and benzene soluble organic fraction of particulate matter in an urban area of Kolkata. India. Environ Monit Assess 115(1-3):205-222

Hagenbjörk A, Malmqvist E, Mattisson K (2017) The spatial variation of $\mathrm{O}_{3}, \mathrm{NO}, \mathrm{NO}_{2}$ and $\mathrm{NOx}$ and the relation between them in two Swedish cities. Environ Monit Assess 189:161. https://doi. org/10.1007/s10661-017-5872-z

Harrison RM, Jones AM, Lawrence RG (2004) Major component composition of PM10 and PM2.5 from roadside and urban background sites. Atmos Environ 38:4531-4538
Hayes SR (1991) Use of an indoor air quality model (IAQM) to estimate indoor ozone levels. J Air Waste Manage 41(2):161-170. https://doi.org/10.1080/10473289.1991.10466833

IEA (2017) Energy Policies of IEA Countries. Poland. 2016 Review, IEA Publications, International Energy Agency, France

Inness A, Baier F, Benedetti A et al (2013) The MACC reanalysis: an $8 \mathrm{yr}$ data set of atmospheric composition. Atmos Chem Phys 13(8):4073-4109. https://doi.org/10.5194/acp-13-4073-2013

Künzli N, Kaiser R, Medina S et al (2000) Public-health impact of outdoor and traffic-related air pollution: a European assessment. Lancet 356(9232):795-801. https://doi.org/10.1016/S0140 $-6736(00) 02653-2$

Landim A, Teixeira E, Agudelo-Castañeda D et al (2018) Spatiotemporal variations of sulfur dioxide concentrations in industrial and urban area via a new statistical approach. Air Qual Atmos Health 11:801-813

León-Mejía G, Machado MN, Okuro RT et al (2018) Intratracheal instillation of coal and coal fly ash particles in mice induces dna damage and translocation of metals to extrapulmonary tissues. Sci Total Environ 625:589-599

Liu YL, Ge YE, Oliver Gao H (2014) Improving estimates of transportation emissions: modeling hourly truck traffic using period-based car volume data. Transp Res D Transp Environ 26:32-41

Malley CS, Von Schneidemesser E, Moller S et al (2018) Analysis of the distributions of hourly $\mathrm{NO}_{2}$ concentrations contributing to annual average $\mathrm{NO}_{2}$ concentrations across the European monitoring network between 2000 and 2014. Atmos Chem Phys 18(5):3563-3587. https://doi.org/10.5194/acp-18-3563-2018

Martinello K, Oliveira MLS, Molossi FA et al (2014) Direct identification of hazardous elements in ultra-fine and nanominerals from coal fly ash produced during diesel co-firing. Sci Total Environ 470-471:444-452

Menut L, Goussebaile A, Bessagnet B et al (2012) Impact of realistic hourly emissions profiles on air pollutants concentrations modelled with CHIMERE. Atmos Environ 49:233-244. https ://doi.org/10.1016/j.atmosenv.2011.11.057

Moreno T, Karanasiou A, Amato F et al (2013) Daily and hourly sourcing of metallic and mineral dust in urban air contaminated by traffic and coal-burning emissions. Atmos Environ 68:33-44. https://doi.org/10.1016/j.atmosenv.2012.11.037

Nicolai T, Carr D, Weiland SK et al (2003) Urban traffic and pollutant exposure related to respiratory outcomes and atopy in a large sample of children. Eur Respir J 21(6):956-963. https:// doi.org/10.1183/09031936.03.00041103a

Oliveira MLS, Pinto D, Tutikian BF et al (2019) Pollution from uncontrolled coal fires: continuous gaseous emissions and nanoparticles from coal mining industry. J Clean Prod 215:1140-1148

Pérez N, Pey J, Cusack M et al (2010) Variability of particle number, black carbon, and $\mathrm{PM}_{10}, \mathrm{PM}_{2.5}$, and $\mathrm{PM}_{1}$ levels and speciation: influence of road traffic emissions on urban air quality. Aerosol Sci Technol 44(7):487-499. https://doi.org/10.1080/0278682100 3758286

Putaud J, Raes F, Van Dingenen R et al (2004) A European aerosol phenomenology - 2: chemical characteristics of particulate matter at kerbside, urban, rural and background sites in Europe. Atmos Environ 38(16):2579-2595. https://doi.org/10.1016/j.atmos env.2004.01.041

Ramírez O, Sánchez AM, Amato F et al (2019) Physicochemical characterization and sources of the thoracic fraction of road dust in a Latin American megacity. Sci Total Environ 652:434-446

Saikia BK, Saikia J, Rabha S et al (2018) Ambient nanoparticles/ nanominerals and hazardous elements from coal combustion activity: implications on energy challenges and health hazards. Geosci Front 9:863-875 
Schneider IL, Teixeira EC, Agudelo-Castañeda DM et al (2016) FTIR analysis and evaluation of carcinogenic and mutagenic risks of nitro-polycyclic aromatic hydrocarbons in PM1.0. Sci Total Environ 541:1151-1160

Servillo L, Atkinson R, Smith I, Russo A, Sýkora L, Demazière C, Hamdouch A (2014) TOWN, small and medium sized towns in their functional territorial context, Final Report, Espon, Luxembourg

SP (Statistics Poland) (2017) Environment 2017. Statistical information and elaborations. Statistical Publishing Establishment, Warsaw

SP (Statistics Poland) (2018) Statistical yearbook of the regionsPoland. Statistical Publishing Establishment, Warsaw

Tecer LH, Tagil S (2014) Impact of urbanization on local air quality: differences in urban and rural areas of Balikesir, Turkey. CLEAN Soil Air Water 42(11):1489-1499. https://doi.org/10.1002/ clen.201200640

Vouitsis I, Amanatidis S, Ntziachristos L (2015) Daily and seasonal variation of traffic related aerosol pollution in Thessaloniki, Greece, during the financial crisis. Atmos Environ 122:577-587. https://doi.org/10.1016/j.atmosenv.2015.10.008
WHO (World Health Organisation) (2000) Air quality quidelines for Europe. WHO Regional Publications, Copenhagen

WHO (World Health Organisation) (2005) Air Quality Quidelines for Europe. Global Update 2005. WHO Regional Publications, Copenhagen

Wielgosiński G, Czerwińska J, Namiecińska O, Cichowicz R (2018) Smog episodes in the Lodz agglomeration in the years 20142017. In: E3S web of conferences vol 28, p 01039. https://doi. org/10.1051/e3sconf/20182801039

Zhao X, Zhang X, Xu X et al (2009) Seasonal and diurnal variations of ambient $\mathrm{PM}_{2.5}$ concentration in urban and rural environments in Beijing. Atmos Environ 43(18):2893-2900. https://doi. org/10.1016/j.atmosenv.2009.03.009

Zheng J, Zhong L, Wang T et al (2010) Ground-level ozone in the Pearl River Delta region: analysis of data from a recently established regional air quality monitoring network. Atmos Environ 44(6):814-823. https://doi.org/10.1016/j.atmosenv.2009.11.032 